\title{
From Peripheral Domination to Internal Colonialism: Socio-Political Change of the Lakota on Standing Rock*
}

\author{
by \\ James V. Fenelon \\ Assistant Professor \\ Sociology Department \\ John Carroll University \\ University Heights, Ohio 44118 \\ U.S.A. \\ ifenelon @.jcvaxa.jcu.edu
}

Cite: Fenelon, James V. (1997). "From Peripheral Domination to Internal Colonialism:

Socio-Political Change of the Lakota on Standing Rock." Journal of World-Systems

Research 3: 259 - 320.

C 1997 James V. Fenelon

*Paper first presented with First Nations and Social Change research paper panel at the American Sociological Association New York, New York

[Page 259]

Journal of World-Systems Research

\begin{abstract}
This paper discusses changing "national" identities of the Lakota and Dakota on Standing Rock, "Sioux" Indian Reservation, through an overview of the traditional Lakota, the United States, conceptual differences of Lakota Oyate with U.S. sovereign power, and political representations. Envelopment / incorporation of the Lakota are discussed as struggles over sovereignty and treaty rights leading to formation of the "Sioux Nation" and six separated Lakota-Sioux reservations. External national identities range from "Hostiles" alien labels to "Indians" ultimately as citizens. American citizenship is reviewed as both inclusion and dissolution, with the re-organization, political re-construction, and assimilation strategies of the United States. 20th century Resistance and cultural domination are considered in the American Indian Movement as political resurgence.

I find four major sources and forms of "nationalist" identities on Standing Rock, arising from two "temporal" periods using world systems analysis : the 19th century semiperipheral domination over the Lakota by the U.S. government, and the 20 th century imposition of internal colonialism, especially with the B.I.A. and modern tribal councils. These forms -- progressive and resistance, assimilated and traditional, -- are further tempered in contemporary political and social discourse, especially by Indian activism and cultural survival.
\end{abstract}




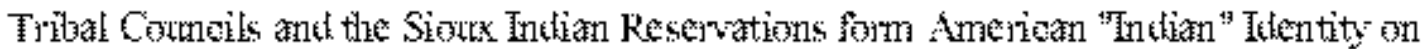

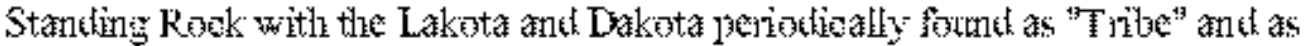

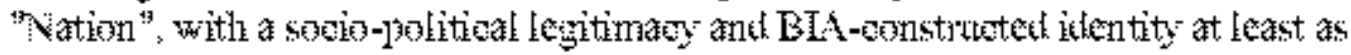

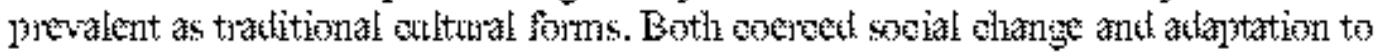

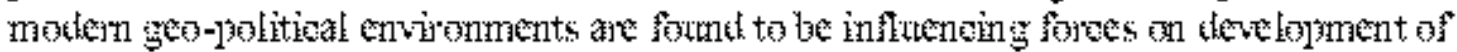

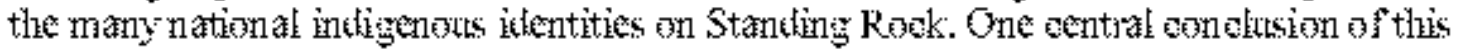

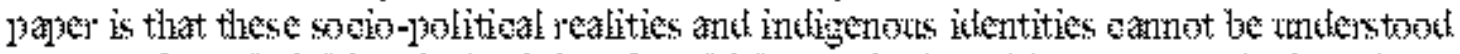

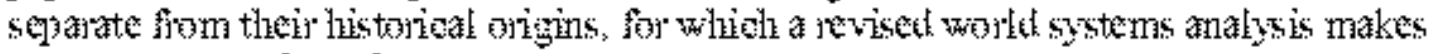

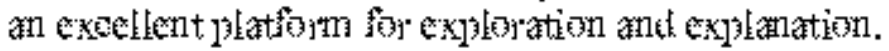

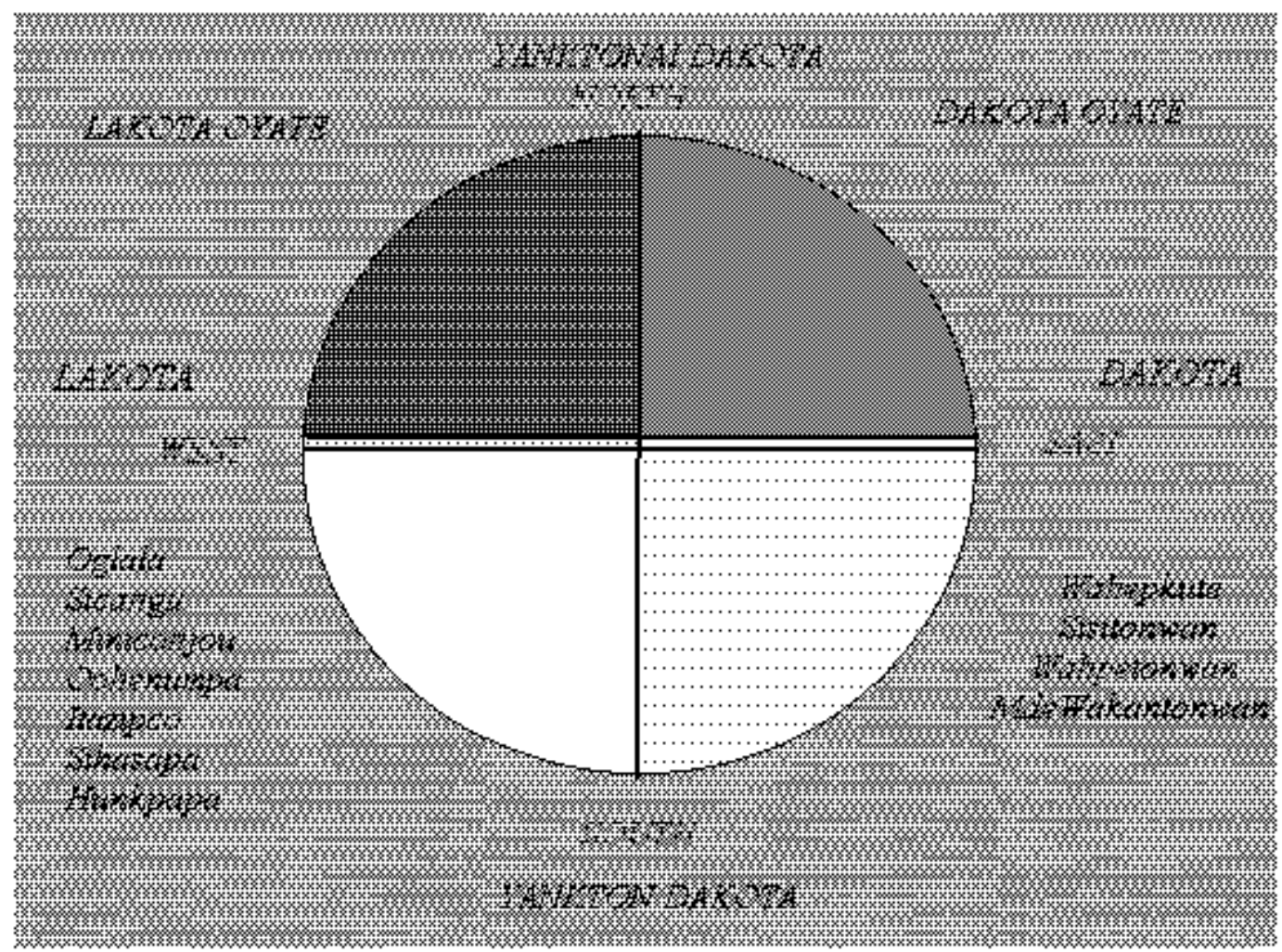

\section{Preface}

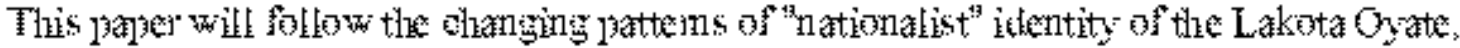

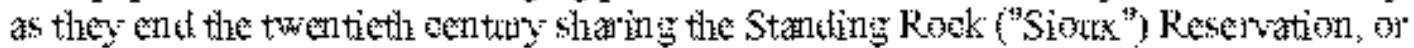

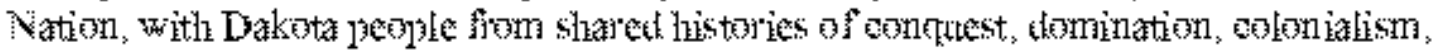

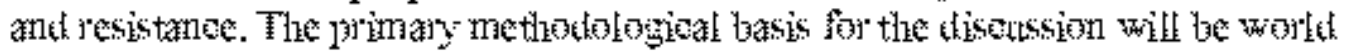

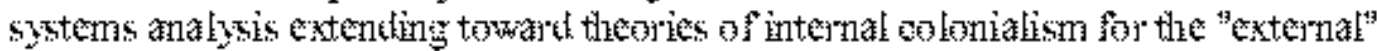

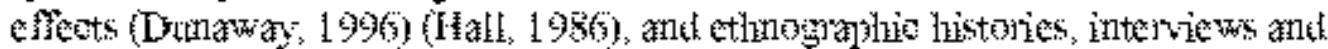

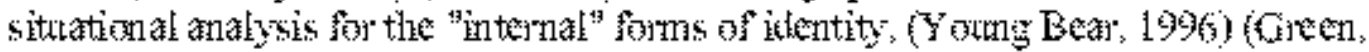
$1995)$.

[Page 260]

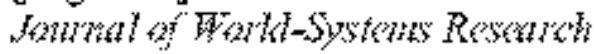


Two important comments about the use of indigenous "identity" need to be delivered: First and foremost is that the dominating force, in this case the United States, manipulates and controls identity labels as part of its tactical repertoire (Biolsi, 1992), thus leading to "external" identities; Second is that the subordinated or oppressed group, in this case the Lakota peoples, often experience fractured and contrived identity forms in terms of its resistance (Parman, 1994) (Castile, 1992) (Deloria, 1990), leading toward differentiated "internal" identities.

Reviewers for the original form of this paper were concerned with the effects of recent activism on identity constructions, which I would suggest is really a secondary or even tertiary topic for world systems analysis. Another, more problematic issue permeates that set of issues -- conclusions arising from those works on activism, seems to imply that most Natives, including traditionals on the reservations, were inactive and waiting for the intervention of an outside force in order to make claims to sovereignty and the identity constructions associated with those claims. Although many analysts observe the influence of these activists on particular events and social movements (Johnson, 1996) (Nagel, 1995) (Cornell, 1988), their overly strong claim as to the "shaping of identity" as found in terms like "retraditionals" and "supratribal" are generally true primarily and in some cases only for "urban Indians" or those Natives working outside of strong reservation or Indian "Nation" situations, which are the legacy of the expanding U.S. systems, (Hall, 1989). The ambiguities of these situations do not belong in work that analyzes devolution of Hunkpapa Lakota to the Standing Rock "Sioux" with Yanktonai Dakota (Defender, 1990). Moreover, many Native people and institutions on Standing Rock are critical of such identities, while others readily embrace them. 1

These differences are a problem in our field of Sociology, since most of us want to imply that modern, observable forces are shaping re-newly identified resistance that have actually been going on all along. Another reviewer found at least three papers in the original work on identity, with a focus on social degeneration from resistance on the tribal or national levels, to that of reservation-based identities. For analytical purposes, there are almost two separate populations -- reservation-based peoples with demonstrable claims to "Tribal" and "Indian Nation" sovereignty, and subsumed Natives usually associated with urbanized areas without any federal recognition, whose identity constructs are more of those arising from "minority group" resistance, resembling those of African-Americans and Latino-Chicanos. Both of these organizational groups behave in very different ways for very different purposes.

Unfortunately, some Native researchers and the majority of non-Native scholars focus on, and base their analysis on, more easily observed events and people associated with activist groups. This paper will give weight to the "traditionals" and "Indian Nation" leaders who for generations have "preserved their ways of life" against all odds (White Hat, 1990).

[Page 261]

Journal of World-Systems Research 


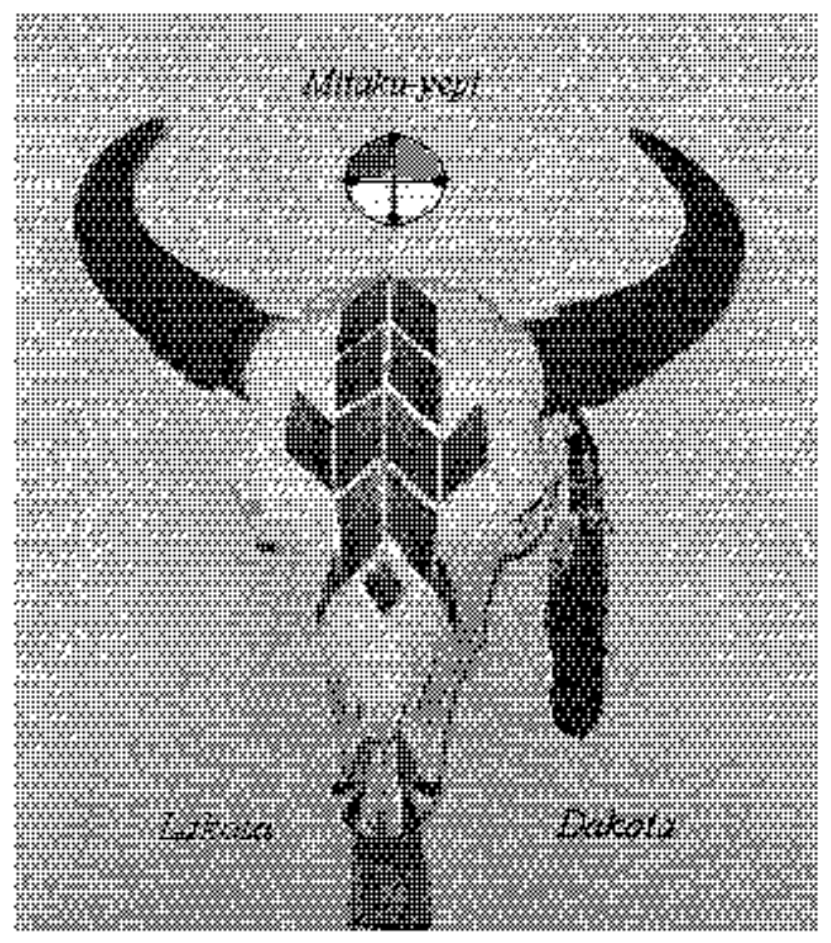

\section{Oreriew}

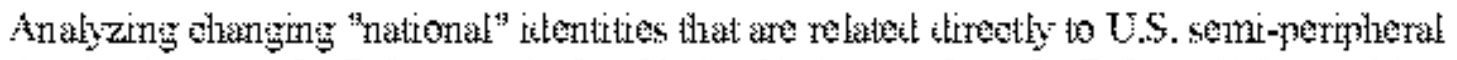
tomination over the Lakota, antil other Native Nations stele as the Dakota, links workt-

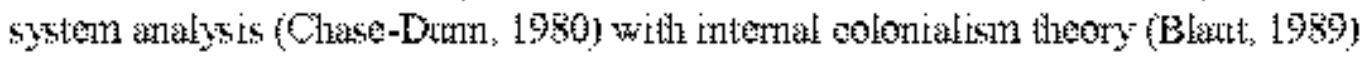

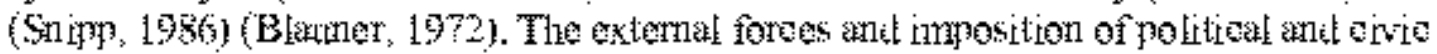

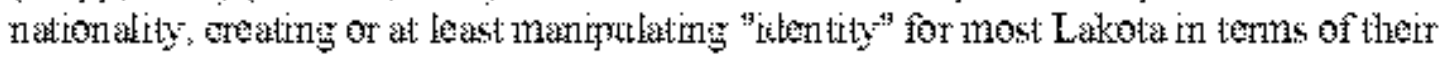
relations with the Unital States, has thereby often conflietel with intemal forms of Lakota itentity (Powers, 1986), spedifeally thowe who see themselwes as "traktitional" in any of the time jeriois (Wakkr, 1982).

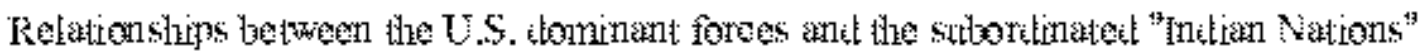

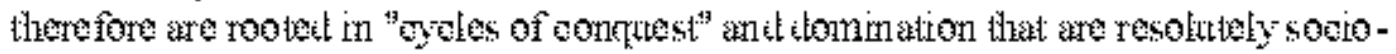

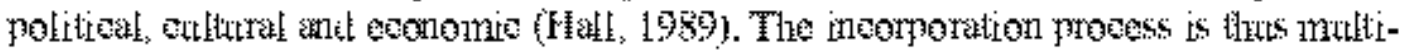

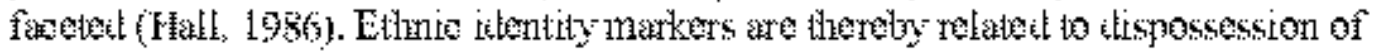

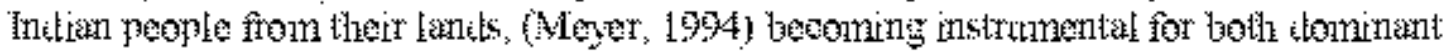

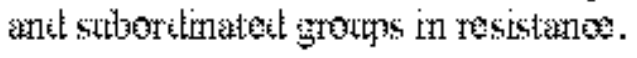

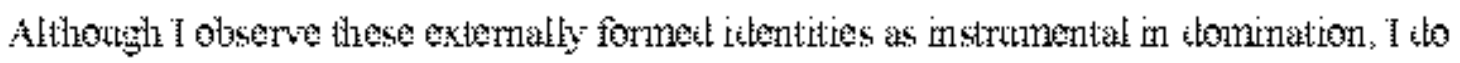

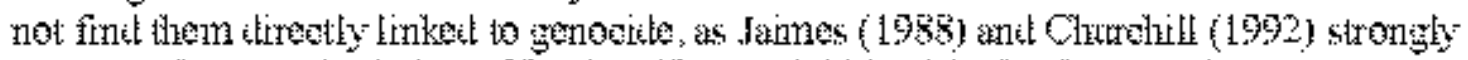

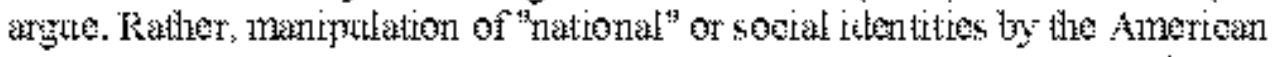

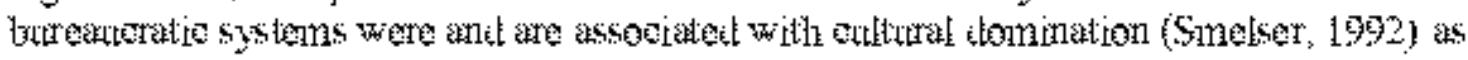
a tool of werene assinilation polieies pat of a larger incorporation or exelusion

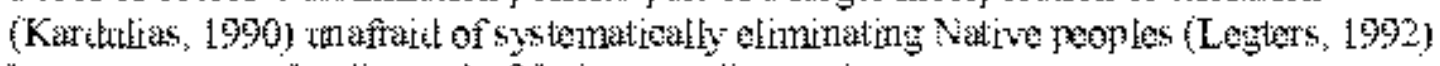
by any means at the tisposal of their expanting soeiety. 


\section{Introduction}

Native American Indian identity remains one of the most amorphous, changeable cultural constructs in social practice today. Cultural, political and social institutions unique to Native peoples influence every aspect of identity for indigenous people who reside on or near, or maintain close contact with their home communities and lands. Additionally, historical shifts in U.S. governmental policy treatment complicate so-called tribal affiliation and acknowledgment, amplifying the national origin issues (Green, 1995).

The Lakota (Teton-Sioux) remain an excellent example of the multi-modal, intertwined issues of indigenous identity, partly because of the temporal periods of maximized contact and conflict overlap extremely well with the U.S. government's various Indian policies. Development of separate Sioux (Lakota) Indian reservations demonstrates the further fractionation of identity by the U.S. Bureau of Indian Affairs. Standing Rock (Sioux) Indian Reservation, or "Nation," illustrates all of these issues, along with the removal and placement of allied yet culturally different peoples into one, partially amalgamated socio-political structure.

[Page 262]

Journal of World-Systems Research

Contemporary forms of Native identity on Standing Rock are partially a result of these forces and the resulting social change, accompanied by a renewed and energized Indian activism. This paper "Socio-Political Change of Lakota to the Standing Rock Sioux" explores and analyzes these issues in terms of historical shifts and changing forms of identity among the Lakota and Dakota people on Standing Rock.

Traditional Lakota follow the oral tradition in naming their origin place as the Black Hills and surrounding points (Goodman, 1992).2 Methodological tensions between oral tradition and western historical sources, demonstrate the complexity of sorting out misconceptions from both fields of identity interest. Arvol Looking Horse, a well-versed Lakota traditionalist, relates both perspectives, describing himself as "the nineteenth generation to serve as (sacred) Pipe keeper," given to the Lakota near the Iron Lightning community on Cheyenne River Reservation, (DeMallie, 1987:67-8) placing the Lakota west of the Missouri four hundred years ago. In the same account, Looking Horse (pg.71) says "our people used to be probably in the Minnesota area, or eastern South Dakota," reflecting a standard migration history from the textbooks found in schools, with a clear influence on modern Lakota who attended those schools.3

For contemporary purposes, respecting traditional histories as much as scholarly notions, we find the Lakota in seven major groups: the Oglala, Sicangu (Brule), Miniconjon, Oohenumpa (Two boils Kettle), Itazipco (Sans Arc or No Bow), Sihasapa (Blackfeet), and Hunkpapa, existing westward of a northern plains fringe near Minnesota woodlands. While Lakota regularly moved through the eastern Dakotas preceding the 17 th century, and the western regions as well, with advent of the horse and pressure from their Dakota allies, some Lakota groups re-entered more forcefully unto the central Dakota plains 
including the Black Hills by the early 1700 's.4 Thus, their historical lands of origin were politically strengthened by allied Lakota groups.

However, reification of Euro-American social structures, as "tribes" versus nation-states, (Dunaway, 1996) (Wolf, 1982) over-simplifies the processes at work. The nomenclature above are culled from Walker's early writings (1917), with primary emphasis on the Lakota. Therefore, he consistently refers to the overall Teton and Santee (Sioux) people as the Lakota. However, most textbook references and nearly all of the major contacts with a "white" people government, as well as major Indian nations reporting direct conflict to European powers, are of the Dakota. Thus most linguistic and cultural works refer to the "Siouxian" "tribes" as the "Dakota" peoples.

[Page 263]

Journal of World-Systems Research

In many of the traditional circles, however, Dakota refers to a most common-used dialect, including the Yanktonai or the Northern Dakota, just as Lakota refers to the so-called Ldialect, used exclusively by the Titonwan people, commonly referred to as the Lakota. Complicating matters more is the knowledge that other allied peoples used the Nakota language, or N-dialect. Since these languages are associated with the so-called "middleSioux" referring to the region between the easterly Santee-Dakota and westerly TetonLakota, the Yanktonai and Yankton often find themselves given status as Nakota people. Additionally, with circumscribed attempts putting "politically correct" labels in place, each is often referred to as "nations" with the Lakota, "Nakota" and Dakota nations not conforming to accurate geographic history. In this analysis, traditionalists refer to the above groups as Lakota Oyate, versus assimilated "Sioux" with U.S. labels, and "nations" are used only comparatively with modern socio-political interpretations.5

\section{Overview of the Lakota and the United States}

Over a two hundred year period the "Lakota Oyate" experienced cultural domination through sublimation and elimination of Lakota societal integrity and cultural practices by the U.S. during conquest of the central plains (Josephy, 1992). I find processes of selective extermination, inferiorization and coercive assimilation of the Lakota, identified in three phases of "conquering" modes for socio-political domination, "profiteering" modes for sustained economic exploitation, and "culturicidal" modes for social systemic domination. Each and every mode of domination targeted, manipulated or deeply influenced forms of indigenous Lakota identity. 6

Many of these coerced changes in identity were on the ideational level7 (Berkhofer, 1979:123). Dakota and Lakota leaders and scholars responded by invoking "ancestral rights"8 emanating from a close relationship of the people with the land (Standing Bear, Lakota, 1933). However, United States land interests were from the start based on declarations of sovereignty, (Deloria and Lytle, 1984). 
Therefore, I distinguish between external identity forms, primarily coming from the U.S., (Green, 1995) and internal forms of identity and knowledge-building traditions (Whitt, 1995), resulting from changes in traditional Lakota social practices. Furthermore, I maintain focus on temporal periods based on the dominance of U.S. institutions (Grinde, 1995), including much conquesting during the early nineteenth century, conquering and profiteering during the 1800 's, and continued profiteering with cultural domination over the turn of the century into the 1900 's.

The nature of these conflicts is "masked" by the comparative systems employed (Wilkins, 1995).

\section{[Page 264] \\ Journal of World-Systems Research}

The problems of migration theory, especially with twisted examples of the Lakota-Sioux, are evidenced in many documents by an over-reliance on mainstream and military historians such as Prucha $(1990,1975,1984)$, Vestal (1963), and especially Utley (1984, 1983). References to U.S. views of a western "permanent Indian frontier" with "little economic value" are found false, indicated as early as 1804 by Lewis and Clark's instructions from President Jefferson as to value, (Ronda, 1984). Declarations of sovereignty for purposes of controlling riverine trade networks, and later mineral resources, were the central political motivation from 1804 until 1868. Even so, the models are perpetuated by contemporary curricula including those disseminated on Standing Rock reservation, partly as a result of hegemonic interpretation of Lakota identity.

Common problems such as "white travelers were frightened by the turmoil and commotion caused by intertribal raids" (North Dakota DPI 1995 curriculum) underscore differences rather than alliances based on identity, suppressing information about the general invasion under way, predicated by all three divisions of the U.S. government. In this way, noted "intertribal raiding" serves as analytical justification after the 1851 treaty (White, 1978), producing an understandable intervention by the United States. However, the "treaties" were broken by the U.S. government, military and civilian forces under the pretext of various identity labels including that of "hostile" usually applied to nonassimilated, resisting Lakota (Wilkins, 1995:95). Therefore, discussion of traditional Lakota cultural identity must precede the conflict analysis of social change.

\section{Traditional Lakota Culture and Identity Forms}

In traditional Lakota culture, responsibility towards relatives, sacredness and sovereignty, extend outward in networks of extended relationships, ultimately reaching the notion of "nation."

Walker (1914) captures these notions: "The Lakota taku-kiciyapi (consider-one-anotherkindred), because they are all either owe (of-one-blood), or oweya (considered-of-blood), with ancestors oyate unma (other people)... Lakota divide into seven otonwepi (i.e. 
Teton), and seven ospayepi (i.e. Oglala)... Oglala divide into seven ti-ospayepi (tipi divisions); each tiyospaye is composed of one or more wico-tipi (camps), and each camp is composed of two or more ti-ognakapi (husbanded tipis)... Thus the strength of the relationship of one Lakota to another is in the following order: 1, ti-ognaka; 2, wico-tipi; 3, ti-ospaye; 4, ospaye; 5 , otonwe." (1914:97-98)

Therefore Lakota range from household, to family-neighbors (village), extended relatives, (associated villages and hamlets similar to a movable town with outlying districts), to large groups with many allied "camps" such as a "tribe" or "band," to relatedness alliance on the "nation" level, with otonwe (by blood) and oyate (common society). Every level commands greater attention to being a "good relative" and person, so that political relations with oyate unma or "other people" follows these ordering principles. U.S. representatives consistently failed to acknowledge this, until it became to their political advantage to forcibly separate these divisions of identity.9

[Page 265]

Journal of World-Systems Research

Preceding arrival of Euro-American governments, the Lakota viewed themselves as Oyate, or "the people" with Ikce as Native (Walker, 1914) or common together, that can be applied to any substantial grouping, including the largest groups of all "Sioux" Dakota, Lakota and Nakota (Powers, 1986). Seven major "tribal" affiliations are associated with the "Sioux" (Walker, 1982), Dakota "Oyate" of Mdewakantonwan, Wahpekute, Wahpetonwan, Sisitonwan, "Dakota speakers" of the Ihanktonwan (Yankton), Ihanktownanna (Yanktonai), and the "Lakota speakers" Titonwan usually referenced as the "Teton" (see Walker, 1982, pg. 14-20) or the Lakota.10

These socio-political and kinship alliance systems are represented in the "Oceti Sakowin" or "seven council fires" comprised of all seven major groups. There are also ancient divisions, including with the Assiniboine and other indigenous "tribes" or nations from the grand alliances, such as the Cheyenne and Omaha. While scholars (Walker, 1982) (Meyer, 1967) debate existence and strength of these networks, without clear resolution (DeMallie, in Walker, 1982), we can say that alliances existed, linguistically and sociopolitically, with the Lakota on western boundaries. As American pressures pushed in from the east and south, and the Ojibwa and northern peoples were pressured by the French and British from the northeast, many loose alliances strengthened, hardening by the time the United States military entered the area. Confederacies began to shape themselves more into "national" identities, especially in relation to other Indian societies.

Also, the European-centered world-system, extending through the American economy, attempted to incorporate and peripheralize the Native population's land and people, transforming relations between people and their environments through commodification and proletarianization, (Kardulias, 1990). However, uneven development and indigenous resistance, (Dunaway, 1996), accounts for the historical transformation from an external arena to periphery of the world system -- an internal "Indian Nation" periphery within the rising semiperiphery of the United States. Full inclusion of the incorporated peoples did 
not occur in the northern plains. Instead, appropriation of land and reproductive resources was initiated through homesteading and the equivalent of land grants to railroads and other private interests with capital development, along with repopulation strategies for immigrant European labor. Thus demographic pressures, alongside the political, conspired to marginalize the indigenous people, the Lakota, as a minority within their own lands. Internal colonialism on treaty land became central to notions of nationality and identity.

[Page 266]

Journal of World-Systems Research

Cultural semantic-mapping of the external definitions of Lakota identities as a chronology explaining Lakota-U.S. interactions and the critical events and identity shifts (internal or external) are explained in the following chart. Four major temporal periods are identiied for this chart: "Oceti Sakowin" loosely allied confederacies; separated "Sioux Nations" with internal divisions; separate "Sioux Indian" reservations for the Lakota; and autonomous Lakota reservation systems, calling themselves "Nation" or "Tribe". I find four major sources of "national" identities on Standing Rock, arising from two "temporal" periods using world systems analysis : the 19th century quasi peripheral domination over the Lakota by the U.S. government, and the 20th century imposition of internal colonialism, especially with the B.I.A. and modern tribal councils. These forms - progressive and resistance, assimilated and traditional, -- are further tempered in contemporary political and social discourse, especially by Indian activism and cultural survival.

[Page 267]

Journal of World-Systems Research

\section{External Constructions of "LAKOTA $O Y A T E "$ and "SIOUX NATION" Identities}

"OCETI SAKOWIN" (alliance of "seven council fires" - Lakota were a council) $\boldsymbol{O Y A T E}$

1700 - LAKOTA as OYATE, YANKTON(AI) as OYATE, DAKOTA as OYATE, NATION

the Lakota, Yankton, Yanktonai, and divisions of the Dakota, can all act as Oyate

1764 - LAKOTA, DAKOTA, NAKOTA - TETON and SANTEE "SIOUX" 11 -

"OYATE"

bio-regional political control regions separate Lakota in Dakotas and nearby areas

1804 - The "SIOUX" - LAKOTA Councils and broad DAKOTA Alliances and Councils while Yankton Dakota negotiated with Lewis and Clark, Lakota controlled the region

Separate "NATIONS" (Santee Dakota, Teton Lakota as separate treaty nations) 12

1851 - Treaties with "SIOUX INDIANS" - Dakota and Lakota "Nations" (multi-tribal) Traverse-de-Sioux - Dakota treaty, Fort Laramie - multi-national (Lakota) compact

1868 - Treaty with "SIOUX NATION OF INDIANS" - the Lakota Oyate (Teton-Sioux) 
Fort Laramie Treaty of 1868 , established U.S. and Lakota geo-political boundaries

1871 - U.S. Treaty-Making Ended - SIOUX TRIBES (Lakota) situated by agencyreservation

National Origin identity internalized sovereignty, limits to external nation constructs

Separate LAKOTA-SIOUX Reservations (U.S. unilateral breakup of Lakota Oyate) 1890 - SIOUX AGENCIES (Lakota divided by "band" into six separated reserves) 13 BIA agencies separated in 1889 with making of Dakota states and huge land takings

1924 - U.S. CITIZENSHIP with federal enrollment on "INDIAN RESERVATIONS" Standing Rock "Sioux" with Yanktonai Dakota, Blackfeet and Hunkpapa Lakota

1934 - "STANDING ROCK SIOUX TRIBE" (six reservations as separate "tribes") 14 Indian Reorganization Act influences separate councils and (BIA) tribal identities

\section{Autonomy by RESERVATION re-established as "Nation" and/or "Tribe" \\ 1970's - STANDING ROCK divided - TRIBAL COUNCIL vs Traditionals/Activists Lakota and Dakota origins and divisions, with Assimilated and Traditional claims \\ 1990 - STANDING ROCK TRIBE as "NATION" (Standing Rock Sioux Reservation) 1995 - STANDING ROCK NATION listed with council, OYATE re-introduced}

The four major temporal periods are related to the major Lakota identities, in these ways:

"Oceti Sakowin" alliances All Lakota culture is "traditional" with signs of early resistance, mostly as differing ideas on political treatment of the "wasicu"

"Sioux Nations" treaties: Progressives as "friendlies" make treaties, the rest are "hostiles" and/or "uncivilized" as traditional Lakota culture is repressed

"Sioux Indian" reservations Progressives collaborate with assimilation policies and "councils," while traditionalists maintain their culture and resist assimilation

Lakota "Nation" or "Tribe" Assimilated progressive Lakota often work in modern institutions, while "Traditionals" know and live their Lakota culture everyday, with Activists and many Bi-Cultural modern Lakota also present.

[Page 268]

Journal of World-Systems Research

Thus four overlapping, loosely boundaried, external identities are present in four time periods. The typologies are "progressive" (friendly), "resistance" (resist change), "assimilated" (adapted) and "traditional" -- as each is defined by and responds to external 
forces of attempted domination, incorporation, elimination and repression by the United States and its inter-American expansion.

\section{World Systems Analysis and Lakota Identity}

These various identities, of internal and external relations, of Standing Rock Sioux people, have their historical roots traced to domination of the periphery and control over "incorporated" and "subordinated" Natives excluded from full participation in a growing world economic system. Each and every set of Lakota identities and historical periods have past and current controversies associated with them. The purpose of this paper is to discuss the various perspectives grounded in a situational analysis of the Lakota undergoing modified incorporation, and at times elimination, through its relations with the United States and American society.

Hall's (1989) discussion of the problematic concept of "tribe" with respect to Native societies in the Southwest demonstrates the key analytic contribution -- besides dominant labels, academic work itself has introduced distortion into understanding these systemic relationships. These biases are precisely what Wolf (1982) warns social science about in his methods chapters. Similarities with long-term "incorporation"of the Navajo, Apache, and Comanche social group formation identity construction are a consequence of both initial conditions of their incorporation, under Spanish, Native Nation, and Mexican pressures before the United States, and subsequent processes of domination and conquest. However, the initial conditions and subsequent processes of incorporation are substantially different for Lakota peoples, primarily because direct conflict, long after economic penetration, occurs in the nineteenth century and only with the United States.

The context of how Lakota "national" identity and their related modes of resistance shift in response to changes in degree of incorporation into the American State and the worldsystem, over two centuries with growing American hegemony, is best explained by world-system theory. More relevant to understanding the "Standing Rock Sioux" as an amalgamated and subordinated population under these institutionalized systems of domination, is a devolution of Lakota identity from confederated alliances, to "national" resistance, to the internally colonialized reservations, and finally to reconstructed "nation" claims with types from all the previous phases of domination. Thus external identity constructions are used in different phases as incorporation and elimination, just as internal forms of Lakota identity are used to resist, modify and maintain traditional culture.

[Page 269]

\section{Journal of World-Systems Research}

Local events and processes for Native nations, in this case particular to the Lakota people, and global/world-system events and phases of expansion are linked, and often fueled by changes outside the "west" of the Northern plains, such as American desire to open land for production, gain access to gold and natural resources, and establish freer transport access across the Plains without interference from Native resistance with claims 
to national sovereignty (Ortiz, 1984). Transportation routes, necessary for Eastern capitalists to enhance their ability to accumulate capital in the far west and in the process continue the climb of the American state into the core, (Chase-Dunn, 1980) (Hall, 1989), were critical to the treaty-making phase of Lakota domination, (Lazarus, 1991), and were a primary link between global and local processes (Dunaway, 1996).

The important point is that all these different identities are, for specific times and places, quite "legitimate." Analytically, to define only one as the central or most important identity, remains ineffectual and incomplete in comparison with changing, manipulated and responsive identities. The theory of incorporation needs to be expanded so that the theoretical discussions encompass non-incorporated peoples who maintain cultural or national identities in subordinated societal roles that reflect positions closer to internal colonialism that slips into cultural genocide, when resistance is mounted that might threaten sovereign power over the engines of production.

Hall (1986) marshalls evidence to make a macro-account about World-System theory, inclusive of early Native Nations in his later work on the southwest (1989) that never effectively treats the processes of ethnic group formation/transformation in their relation to the incorporation processes of subsumed Native Nations. This paper extends Hall's work (1989) on incorporation within terms of ethnic identity as evidence of the processes, both with macro and micro-level effects. Whereas work done on world-system analysis of the fur trade in the northeastern areas, (Kardulias, 1994) as well as developments in southeastern American colonies (Dunaway, 1996), stress early attempts at incorporation of the periphery into the expanding semi-periphery, this analysis begins with United States continental expansion as it effects the northern plains Lakota, ending with a study of the Standing Rock ethnic identities that result from a rich mix of cultural, national, and societal conflicts.

Therefore, the socio-political mechanisms, as connected to the economic motivations, commanding and controlling these processes of conquest, domination, and internal colonialism, remain central to a depiction of the unfolding processes identified above. We now turn to these discussions.

[Page 270]

Journal of World-Systems Research 


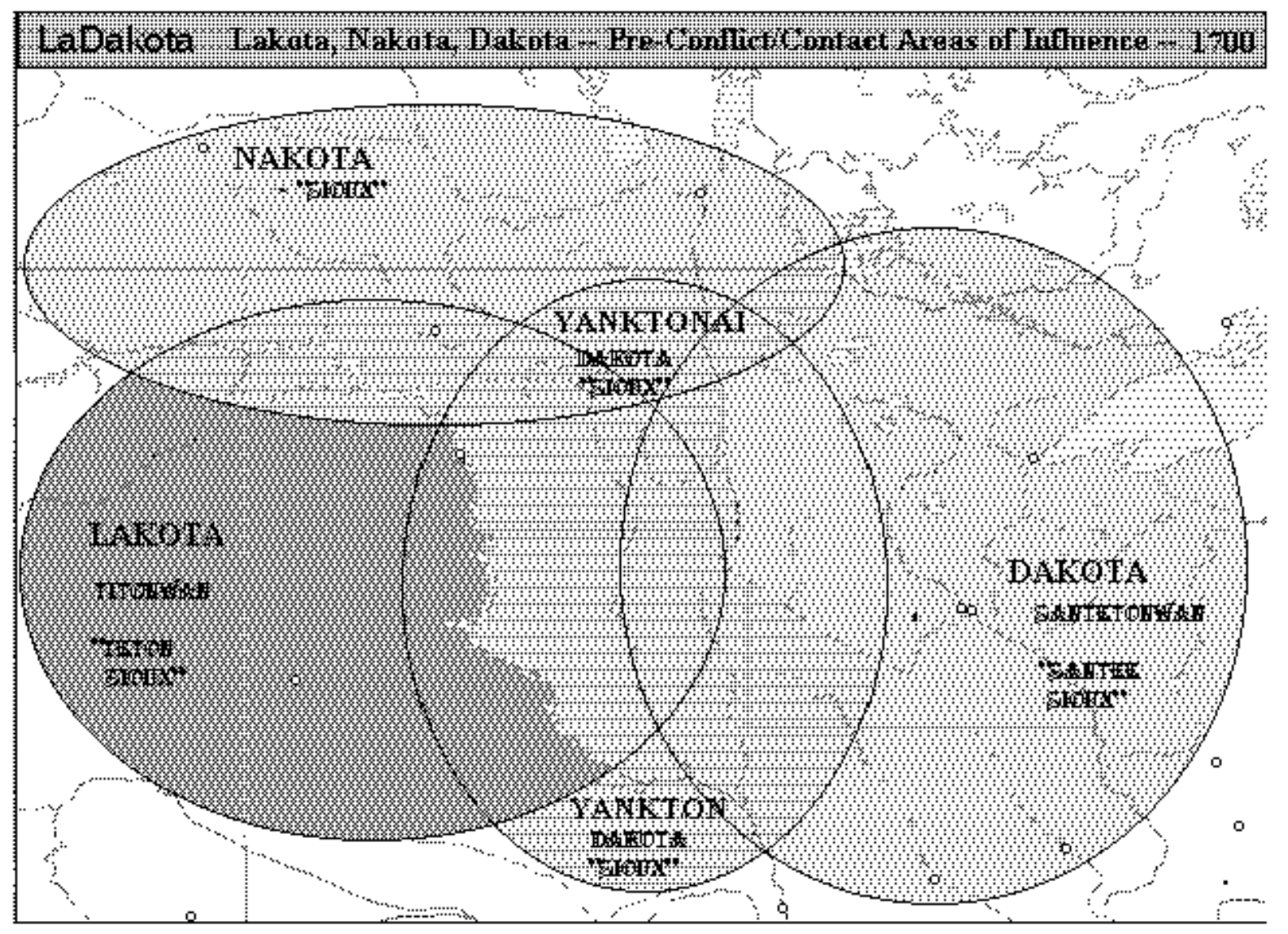

\section{Conquest and Donteration of the Lakota}

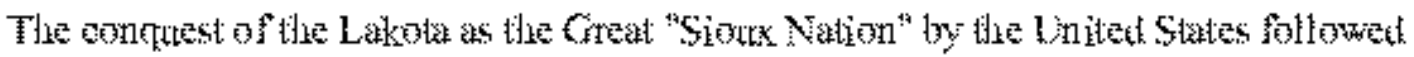

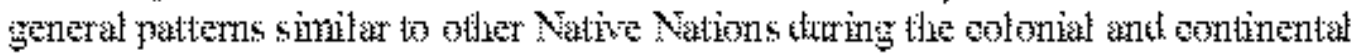

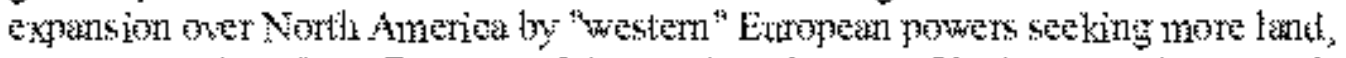

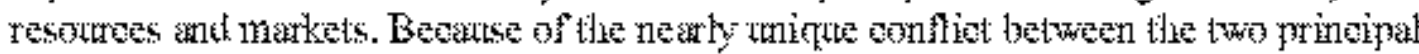

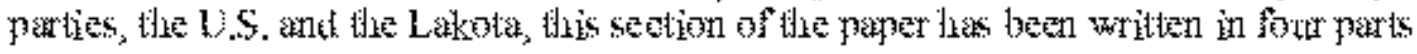

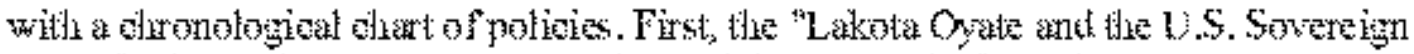

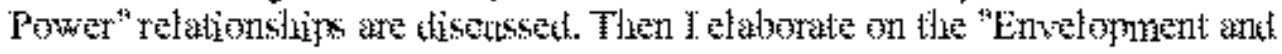
lineorporation of the Lakota" and the ensting "Strugges Orer Sorereignty and Treaty

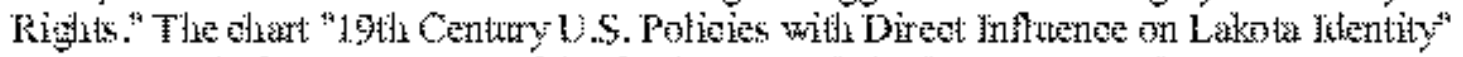

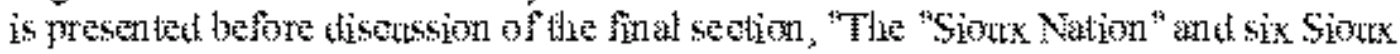

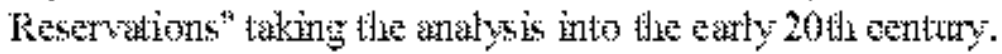

\section{Lakota Oyate and the D. S. Sovereign Power}

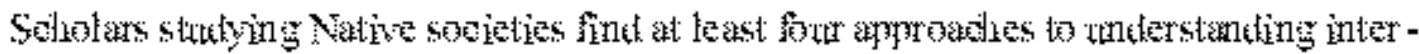

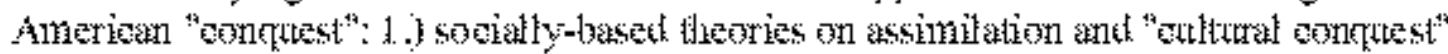

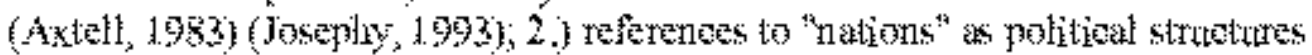

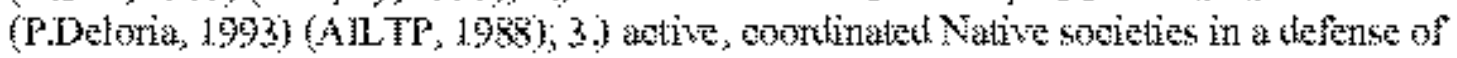

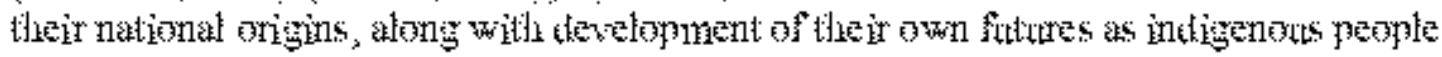


(Ortiz, 1984) (Jaimes, 1992); and 4.) the incorporation of dominated social systems into expanding core state economies (Hall, 1989) (Snipp, 1986). While not exhaustive, each of these approaches require an understanding of the principles and ideologies of the dominating systems.

From 1493 on, European powers extended their control and regional dominance through the processes of declaring sovereignty, implementing conquest, developing forms of colonialism, and establishing cultural domination through internalizing maintenance of total social control.15 These "natural laws" were called the "Rights to Conquest" using the "Doctrine of Discovery" (Wright, 1992) (AILTP, 1988) (Deloria and Lytle, 1984) (Dickason, 1988). The right to a claim of sovereignty, based on judicial constructions of "Indian" identity and "American" citizenship, (Wilkins, 1995), were manipulated to take over and define "Indian land rights" (Coulter and Tullberg, 1984).

Thus, issues of identity become closely intertwined with cultural domination and conquest, (Grinde, 1995), specifically for the relations between the Lakota and the U.S. (Lazarus, 1991). Assimilation theories are thus opposed to nationalism theories are opposed to resistance theory. All three relate historical issues of identity, such as Lakota Oyate, to what Tilly (1978) has expressed as issues of "multiple sovereignty," in situations of collective action and revolution. Although not tempered by "complex unfoldings of multiple conflicts" that take into consideration the conditions of how the "situation emerged in the first place" (Skocpol, 1979), the presence of multiple claims, real or potential, on legitimate sovereignty (Wilkins, 1995:82) greatly informs the processes and outcomes of U.S. struggles with Native Nations, premier among these the Lakota. Issues of spirituality and religious significance quickly became contested, and were the fulcrum points for armed struggle in 1876 and 1890 , as well as the primary means of identity adaptation.

[Page 271]

Journal of World-Systems Research

Spiritual and socio-political significance to the pipe used in ceremonial or ritual behavior, as in treaty-making with more complex "tribes" of people grouped together as a nationstate, reflects these relations in terms of identity. The Fort Laramie Treaty of 1868 made between the United States of America and the "Sioux Nation of Indians" (the Lakota), is just such an example. The U.S. ritual leaders, government and military, revered and followed a written word, and saved their pens after signing the paper, taking pictures of themselves sitting in chairs at the treaty site. The Lakota leaders, as representatives of huge camp-circles, revered and followed a spoken word, the holy wind, remembering the smoking of pipes as a sacred bond not to break "visible breath". Although both these means of making a compact between peoples used representation differently, both were also a cultural expression of intent based on identity. It is interesting to note that many modern Lakota refer to themselves as "pipe-carriers" today, reflecting an extension of traditional identity that is historically loaded with aspects of resistance to cultural and political domination. 
Geographic and socio-political change of Lakota identity maintain two underlying themes. The first is that the United States used both brute force and legal chicanery to overcome Lakota resistance. Rather than "cultural inferiority" Weatherford (1991:252) finds "Indian civilizations" "succumbed in the face of disease and brute strength" under "world's greatest arsenal of weapons" and the relentless pressures of Euro-American conquest.16 Citizenship was not awarded so much as dictated or denied based on the dominant group's interest and level of control (Wilkins, 1995).

The other theme is that the United States employed sophisticated cultural domination and elimination to maintain and further its hegemonic control and land tenure alienation strategies, including use of ideological history and manipulation of identities.17 One particularly evident course of action indicative of these relations develops the "legal fiction" of "unceded territory" found in the 1868 Fort Laramie Treaty, led to "Sioux Indian Wars" in 1876 (Lazarus, 1994), Wounded Knee massacre in 1890, and resulted in U.S. Supreme Court decisions in the 1980's. Thus, identity issues cannot be separated from governmental treatment of the Lakota as Indians, and further is integrally connected to the status of various Lakota groups as in "reservations," "tribes" that become "minority groups" (Deloria, 1981) or as "domestic, dependent nations."

Socio-Political constructions of the "Lakota Oyate" and "Sioux Nation" identities, however different and at odds in terms of cultural definition, can be typologized in conflict terms that hinge upon the relations between these two sets of nations and peoples. These are grouped within four distinct inter-national governmental relations: the traditional Lakota society period, "Oceti Sakowin"; treaty relations of conflict and conquest as "Separate 'Nations"'; domination and division through "Separate LakotaSioux Reservations"; and re-expressed "Autonomy by a 'Reservation' or as 'Nation' or as a 'Tribe"'previously described. Reflexive and well-integrated individual identities establish their relationship, sometimes independent of the level of assimilation, based on these socio-political constructions.

[Page 272]

Journal of World-Systems Research

As products of a political identification imposed by U.S. government agencies and agents, or conversely as an oppositional orientation toward resistance against those political identities, individuals over time influence changes in "tribal" identity and construction of historical identity, that is no less powerful than their most contemporary cultural and political constructs. These adaptations and social change mechanisms are understood by the people undergoing the process, discussed below by a traditional minded Lakota man, an artist in his 30's, who easily moves into and out of modern American institutional life.

You know they call us "Dog-eaters", an ironic name. It includes ceremonies, food in times of starvation, and respect for a species. The wolf is like our people years ago, before the whites came. ...But the dog has changed and adapted over thousands of years, it has survived. We modern Lakota are a lot like the dog -- we have survived, changed, 
and adapted. But even so, an elder once told me that when the wolf is gone from the land, that could be the end of the Lakota. (Tatanka Ypsipsipcha, Fairbanks, 1995).

The "wolf" above is instructive of traditional Lakota life as an Oyate, as allied nations, even though it is well-understood that life has disappeared. So the "dog" has become metaphor for traditional Lakota living and interacting in a modern world dominated by contemporary American insitutions and an impersonal technology. However, the wolf is lurking in Lakota life, maintaining oral tradition histories and cultural knowledge that represents the foundation upon which Lakota American Indians base their forms of identity. Neither bureaucratic nor cultural constructs are even remotely monolithic in an analysis covering the last two centuries.

\section{Envelopment and Incorporation of the Lakota}

The economic forces enveloping and attempting to incorporate the Lakota also become key features in establishing externalized sources of Indian identity throughout the 19th century. Typification as "hostile" or "friendly" Indians introduced divisive elements into Lakota society. (Olson, 1965) (Deloria and Lytle, 1984). Moreover, in terms of pacification of those Lakota resisting the land-takings and social domination, identification with the dominant social groups could change itself, and be adapted by both the external and internal sources of identity.

An outstanding example of this change of locus of identity is the great leader Red Cloud. Universally acclaimed as the war-leader of the Oglala and allied Lakota during the two or three years of war with the United States military leading to the victorious 1868 Fort Laramie Treaty, including directing younger leaders such as Crazy Horse in tactical warfare, during the build-up and battles of the U.S. summer campaign of 1876 , Red Cloud stayed near the Pine Ridge Agency. Although attempting to represent his people in legal maneuvering all the way to Washington D.C., the 1888 land-takings, 1889 Dakota statehood struggles, and the slaughter at Wounded Knee were all instigated without serious resistance from the once great leader living in an agency house. Political and economic incorporation similar to Red Cloud's experience essentially negated ability to resist cultural domination as an integral part of Lakota leadership on the tiyospaye, otonwepi, and oyate levels of identity.

\section{[Page 273]}

Journal of World-Systems Research

Along with the problems of individual leadership and social practices influenced by identity changes in terms of being a Lakota man or woman, the notions of identity orientation with Lakota society was similarly affected, causing less effective claims and practices of sovereign relations. Although arguably a natural outgrowth of the American expansion unto and over the northern plains area, the history of treaties, wars, and diplomatic agreements between the United States with the Lakota makes a fine predictor for how external identity constructions were regularly employed as a means to an end -- 
whether that is elimination, incorporation, or subordination. The undying key to those relations is the notion of "sovereignty."

\section{Struggles Over Sovereignty and Treaty Rights}

Contact history between American representatives and the "Sioux" is complex with ethnic and temporal variations. (Powers, 1975:3-10).18 The word Sioux is a foreign label19 (Robinson, 1904) (Walker, 1914) (Boas and Deloria, 1932).20 The Santee Dakota had "contact" much earlier than the Lakota, documented by Radisson in 1660 , subsequent encounters by La Sueur in 1700, Carver in 1766, and first official contact, Lt. Pike in 1805, to establish "American sovereignty" (Powers, 1975), followed by expeditions to build forts by Major Long in 1817. That history of confrontations culminated in the "Sioux Uprising" of 186221 (Anderson, 1984). The Yankton and Yanktonai suffered the results of buffering the Lakota in 1862 (Meyer, 1980 (1967)).

The Lakota occupied the plains from the Missouri to the Yellowstone and Platte. Teton Lakota were signatories to the multi-national Fort Laramie Treaty of 1851, about the same time Santee Dakota were forced to sign the 1851 Traverse des Sioux Treaty. Two Sioux "Nations" had treaties with the U.S. in 1851 (Meyers, 1980; Lazarus, 1991). We observe how "Sioux Indian" identity is constructed by the U.S. institutions. These "constructions of ethnicity, citizenship and nationality" were mediated by the dominant group's political constructs and cultural determining, partly or completely to reduce claims to sovereign Lakota identity, and thereby treaty rights. 22

\section{9th CENTURY U.S. POLICIES WITH DIRECT INFLUENCE ON LAKOTA IDENTITY}

1803 and 1804 - "The Louisiana Purchase" (and the Lewis and Clark Expedition)

produced the first issue of conflict relations over sovereignty claims made by the U.S., defining Lakota Titonwan as "Sioux" under American political governance

[Page 274]

Journal of World-Systems Research

1830 - Indian Removal Act (Cherokee precedence for all other Indian Nations)

established separation of Indian identity from origin lands as a matter of law and practice, attempted unsuccessfully against the Lakota (Teton) Sioux on multiple occasions

1868 - Fort Laramie Treaty of 1868 (The Sioux Nation of Indians)

established the Great Sioux Reservation and future dealings with the Lakota Sioux as a Nation, becoming the reference point for all discussion about the Black Hills takings 
1871 - Act of March 3,1871 (ending treaty-making with Indian Nations)23

first of many attempts to incorporate Lakota Indians into American nationality without rights of citizenship, essentially dissolving inter-national relations

1876 - Declaration of "Hostiles" transfer responsibility to the Secretary of War legal definition of resisting Lakota as "hostiles" allowing military and civilian repression, dividing Lakota groups, families and individuals, into "for" and "against" typologies

1877 - Black Hills Act of 1887 (takings of land)

deprived Lakota of essential spiritual identity links to sacred lands, forcing a reservation identity devoid of direct traditional underpinnings and associated religious practices

1881 - Individual Agencies "banning" (the Sundance) and selected spiritual practices

"legal" imposition of Christian religious identity that further broke down community life through banning yearly celebrations of Lakota spiritual identity and leadership

[Page 275]

Journal of World-Systems Research

1883 - Indian Offenses (1882) and Courts listed/enacted by Indian Affairs Commission qualified codes of conduct and judicial practices that hampered or criminalized Lakota traditional identity in the Family, Religion, Economic, and Justice realms of society

1885 - Major Crimes Act (jurisdictional sovereignty continued the above encroachment)

1887 - Dawes Severalty Act (General Allotment Act of 1887)

forced land tenure "ownership" on individual or household levels, breaking the traditional and community tiyospaye relationships and their relevant social identities

1889 - The Great Sioux Agreement of 1889 (Crook Commission enacted above land takings)

1890 - Transfer (again) of responsibility to the Secretary of War - The Ghost Dance 
violent military repression of attempted revitalization of traditional identities through adapted religious practices, forcing any existing spiritual traditions to go underground

\section{The "Sioux Nation" and six Sioux Reservations}

Considerations for establishing the territorial domains of Lakota Oyate, thereby identity, include using fixed analytical frames, 24 sensitive to Standing Bear's ideas about "humanization" as the "true essence of civilization" vested for the Lakota in "the spirit of the land."25 Into the 20th century Ohiyesa (Eastman) finds that the Indian (Dakota) is "reconstructed" in "modern society" built out of "artificial blocks" rather than "natural life" and real landscapes.26 The cultural overlay for these social blocks is government adapted for specific indoctrination of Indians as the Lakota. Over time, these social issues become differently represented by the separate Sioux reservations. Thus the humanness described above, reaching outward from tiyospaye relations to the oyate, became circumscribed by the political constructions of reservations around Indian agencies.

Specifically for the Standing Rock Lakota-Sioux case, a central issue is the "frontier27." Rather than typification of an expanding, colonializing American empire,28 language employed by the United States government on the Lakota as "Sioux Indians",29 deepened cultural stratification and reified discriminatory labels.30 Lakota leaders experienced these real-life divisive stand-offs. 31 Ten major social spheres of Lakota life that underwent drastic social change, reflect the powerful forces altering indigenous identity. The three political spheres of governance, military defense, and judicial enforcement, were eliminated or adapted to U.S. Indian agency control. Since most Lakota leadership relied on special councils and warrior societies, this crucial area of identity was denied to the most potent social leaders.

[Page 276]

Journal of World-Systems Research

The Lakota as an "Oyate" had political systems repressed and eliminated, because "fluid" and continuous systems of governance (Biolsi, 1992) and authority,32 complicated systems for the maintenance of cultural domination. U.S. Indian policy imposed political systems that inculcated non-indigenous interactions which further eroded Lakota social structures.33 This achieved U.S. objectives in land takings and resource utilization, all based on isolated reservation identities constructed by the dominating government.34 Historical research had to identify these processes of domination, "anchoring" theoretical observations in the changing relationships to the land35 (Laduke, 1983), and the "absorption" of American Indians (Lakota) "into the white world"36 (Means, 1983). Thus the external identity and policy constructs of progressives and assimilation were considered detrimental to maintenance of traditional Lakota life, leading to internal identity forms of traditionalists in resistance to "the white man" and his ways.

At least three economic spheres achieved these secondary objectives within the main goal. Land Tenure relations, private ownership of Property, and Trade systems were 


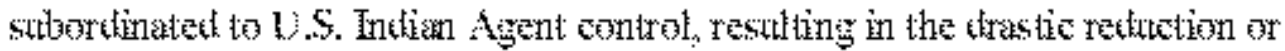

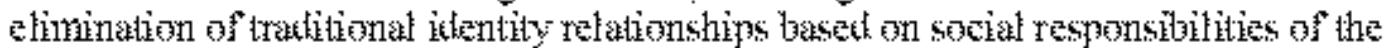

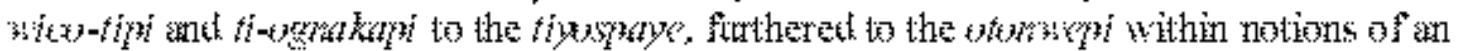
Oyate. Even ingortant give-aneys were bannek.

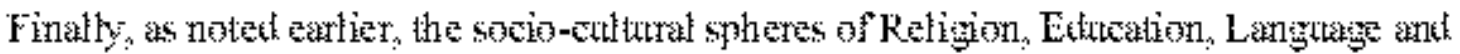

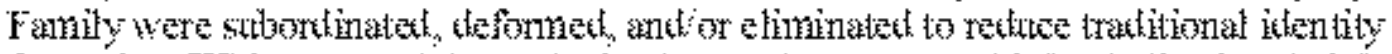

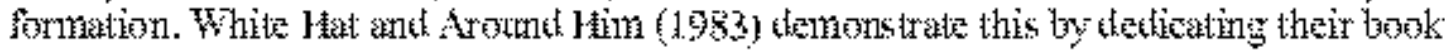

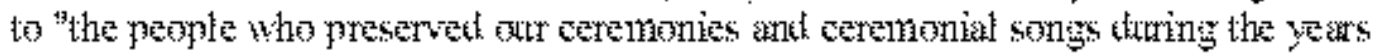

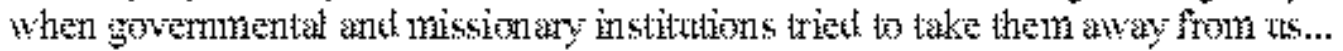

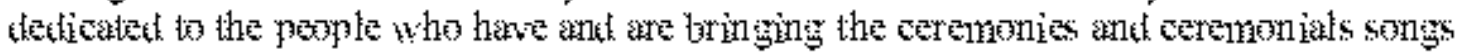
back into their rightfut place in our society -- the Aeticine Aen and Women, the Singers.

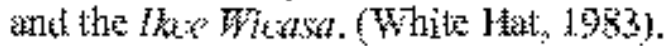

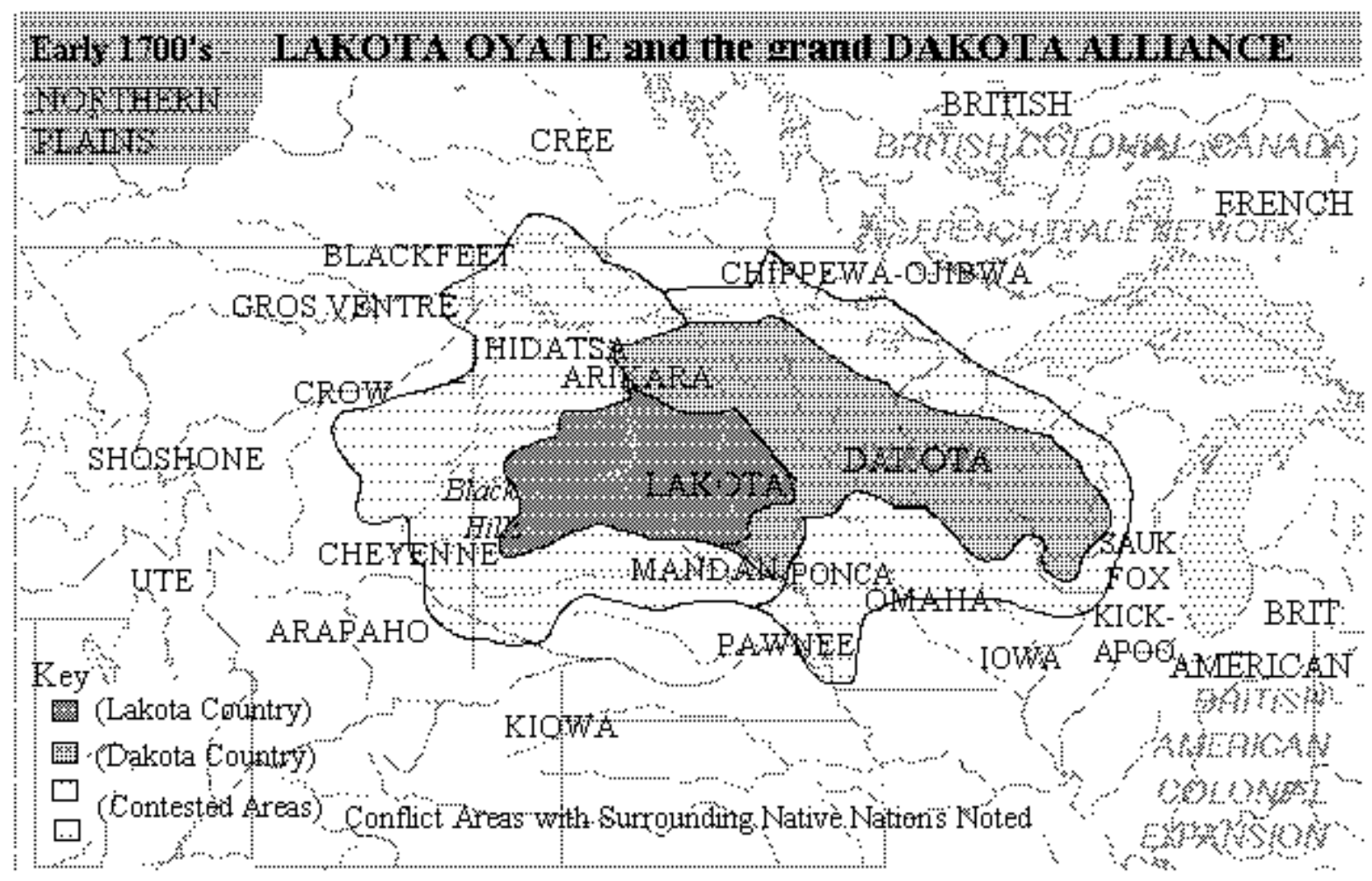

\section{CKABA as fnternal Colonialis na witle Resistance by "Tratitionals"}

\section{From Lostiles and Aliens to lndians a nil Citizens}

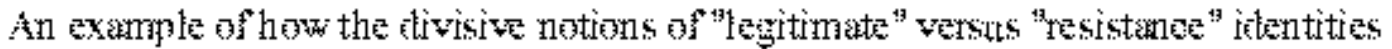

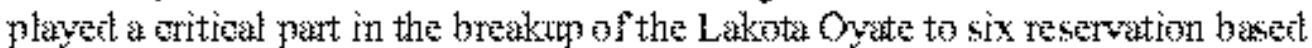

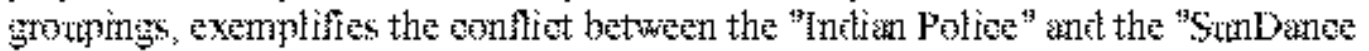

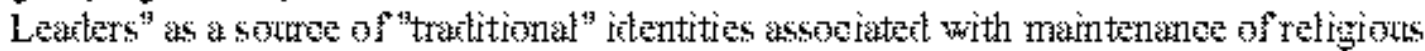

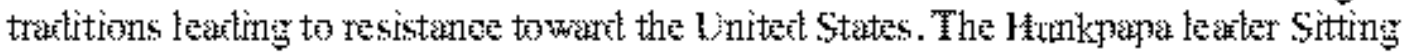

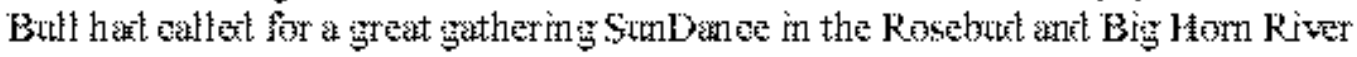


region over the summer of 1876 . When U.S. military forces under Custer attacked them on the Little Big Horn, the Hunkpapa warrior leader Chief Gall was one of three great battle masters that defeated the cavalry. Sitting Bull and Gall lived in Canadian asylum for five years, both coming to rest with their people on Standing Rock. Reservation realities called for the Indian Agent to appoint some leaders to the Indian Police and Courts that criminalized the very practices that made the Lakota so strong a decade earlier. Gall became a judge and supporter of the Indian Police, while Sitting Bull maintained his traditional spirituality and resisted assimilation. During the Ghost Dance fracas, U.S. government and Indian Agency forces targeted and killed Sitting Bull's identity as a well-known "trouble-making source" while his once close friend and war leader Gall conducted an Indian Court on Standing Rock.

[Page 277]

Journal of World-Systems Research

While multiple historical inaccuracies on the "Breakup of the Great Sioux Reservation", denigrate Indian Agents for destructive altercations with the military, a general tone in history places much activity against the Ghost Dance with Agent McLaughlin, when the overwhelming majority of conflict and most military movement happened on Pine Ridge, the Rosebud and Cheyenne River reservations, where senior U.S. officials ordered "the arrests of the leaders." Emphasis on Standing Rock was further misplaced because of the northern Yanktonai Dakota residing on the North Dakota side of the reservation. Besides a successful divide-and-conquer strategy through separated Lakota reservations, assimilated American Indian identities were complicating notions of what a traditional Hunkpapa Lakota represented, at least on Standing Rock "Sioux" Indian reservation, home of the famous resistance leader Sitting Bull.

The concept of the "frontier" being against the "Sioux Indians" as a monolithic whole, gradually was reduced to reservation boundaries as state "frontiers" of sorts, and ended in the identification of individual Lakota as "Hostiles" and dangerous, "Aliens" and thereby suspicious, or/and as generic "friendly" Indians with "potential" for becoming good "Citizens" after proving themselves through living and acting like "the white man" thereby giving up their Indian identity. Incorporation revolved around individual rewards relating to traditional or assimilated identity.

"...(For instance), there are families that curried favor with the military, and to this day, those people get all the benefits, the jobs. ...(in the old days), they would be told 'You're better than those Hostiles, those heathens'..." "(It's particularly bad) when Indians, who claim to be your people, then they tell you that... ...and that if you live out at Cannonball, Bullhead or Little Eagle, you are (unimportant, lower)."

"These Indians are the products of a colonial administration, and so they do the work of the wasicu themselves." (Defender-Wilson, 1996)

American Citizenship: Inclusion or Dissolution? 
American "citizenship" became the contested notions of identity and national allegiance expressed in relationship to the Standing Rock reservation, a greater Lakota or Dakota "tribe", and the United States. Until well after World War One, U.S. citizenship had been utilized as inducement to leave traditional lifestyles and "tribal" membership for assimilation into American economic and social life. This was commonly expressed by both military and civilian authority, (Cadwalader and Deloria, 1983). That strategy never achieved the envisioned "tribal" exodus, nor any secondary objectives of tribal dissolution. It did cause, among the Lakota especially, divisions between those Natives who were more or less assimilated, and further distinctions between so-called "fullbloods" and "mixed-bloods" that continue as identity markers today.

[Page 278]

Journal of World-Systems Research

Through 1924 the United States used blood quantum formulas to determine the tribal membership as against a standard "citizenship" in lieu of the "foreign" status of a Lakota Indian. After the 1924 Citizenship Act all American Indians became citizens. Although beyond the stated purview of this paper, one important point to ponder is whether this was a simple expression of civil rights finally accorded correctly, or was it tactically oriented to speed the assimilation of all "un-reconstituted" Indians? From a mainstream or dominant society perspective, this question appears to be one of governmental motivation and intention (Deloria, 1987 vs Jaimes, 1992). From an indigenous identity perspective, this question colored with the history of one hundred years of cultural domination, appears to be whether inclusion into American society is pitted against dissolution of Lakota "national" or "tribal" society. Distinctions of these identities continue into modern social institutions, including courts of law, schools, and family life.

The primary vehicle for achieving these objectives was the U.S. Bureau of Indian Affairs. Socio-political identity of the Lakota had been manipulated earlier so that "...after the passage of the allotment acts traditional tribal governments did not have legal or bureaucratic status. The allotment policy was intended to make Indians into independent small farmers who would become integrated into the American economic and social system". (Champagne, 1992:35) In terms of recognition of a national identity, the B.I.A. began a different, more benign approach in 1934.

\section{Re-organization: Construction or Assimilation?}

With the 1934 Indian Reorganization Act, Lakota resistance found new forums from which to organize, as well as new bureaucracies which inhibited traditional identity forms. The educated Standing Bear asked whether "the shattered specimen" of the Indian was brought about by "the benevolent conqueror" of the United States, even as sculptors were carving four faces of the most famous U.S. presidents, into a "great shrine of democracy and freedom" on monumental cliffs in the stolen Black Hills, in an area known to Lakota as "the six grandfathers." The Lakota dubbed the Mt. Rushmore result "the four thieves" as each had taken vast tracts of Indian land. Thus the symbol of Lakota 
spirituality was defaced to produce a symbol of American domination. Less symbolic was the attempt to "reorganize" American Indians into Euro-Americans.

Philp (1986) reports that analyst Rupert Costo argued that the Indian Reorganization Act "was the last great effort to assimilate the American Indian. It was also a program to colonize the Indian tribes... The IRA had within its working and in its instruments, such as the tribal constitutions, the destruction of the treaties and of Indian self-government." Deloria and Lytle (1983) find that the I.R.A. was the seed or "inception" points for modern tribal governments. Regardless, after the IRA reorganizations, Champagne (1992:36) finds that "the dominant sentiment in Congress continued to favor assimilationist Indian policies and eventual abolishment of the reservation system," and the "post-World War II period saw resumption of active assimilationist policies within the Indian congressional subcommittees."

[Page 279]

Journal of World-Systems Research

However, another set of seeds had started to grow, for which the B.I.A.'s I.R.A. councils provided powerful fertilizer at Pine Ridge, fueling "Bitter factionalism between full bloods and mixed bloods" that "divided the reservation long before the New Deal." (Parman, 1994:100) "Mixed bloods generally were apt to be more educated, bilingual, and acculturated, and to enjoy success in agriculture or employment. Full bloods tended to be less schooled, more traditional, and still in possession of their allotments."

In terms of identity conflicts, Parman observes: "... a separatist full-blood group known as the "old-Dealers" developed a rival political organization at Pine Ridge and Rosebud... (yet) never sought to control the new councils on the two reservations... (but) instead, regarded them as alien and illegitimate institutions forced upon the Sioux by the BIA and dominated by mixed bloods." (Parman, 1994:101) Biolsi (1992:xxi) identifies the old Dealers "refusal to recognize the IRA tribal councils as governing bodies" and their insistence "Treaty Council was the legal and traditional Lakota body for making tribal decisions" as being consistent "both with Lakota tradition and with (1868) treaty law ."

Defender-Wilson (1996), usually identified as a Dakota traditional from Standing Rock, clarifies this distinction as deeper than the BIA bureaucratic systems:

"...our identity, coming from the earth, (and) from the land, and other people... Just because the federal government didn't put them on a reservation, or give them a number, doesn't mean they aren't Native."

In terms of that consistency of traditional identity being manipulated by government entities, including the depiction of "hostiles" and "savages", she continues:

"I never saw such fine-looking people... We are not a grotesque people, no one should not have made fun of us, because our spirit comes from the land... We left the spider-man 
(Inktomi) behind us in our history -- we are a civilized people. We emerged and learned our ways, and became human beings." (Defender, 1996)

The Dakota and Lakota "civilized people" were precisely the target of the United States. The critical issue became new and continuing traditional identity formation in social institutions. In discussing "Law and Order Apparatus" of enforced domination of the Lakota, Biolsi (1992:7) observes that "technology deployed by the OIA for controlling Indian behavior used the agency courts and police forces," including having jurisdiction over Indian offenses such as "Sun Dance, new plural marriages, practices of medicine men, destruction of property, payment for cohabiting with a woman..." noting punishment for those "who divorced by 'Indian custom'" even though neither agencies nor courts could or would grant divorces. Full-blood (Sioux) Indians were classified as "incompetent wards" with government trusteeship, enabling "competent" individual allottees to remove land from trust through "fee patenting," with the BIA established and run IIM (Individual Indian Money) accounts requiring Lakota people to apply for and defend the use of their money, and "rations" which "allowed direct and immediate control of Indian behavior" by food dependency. Pressures on those Lakota who did not conform or assimilate therefore included direct manipulation of behavior and identity.

[Page 280]

Journal of World-Systems Research

\section{0th century Resistance and Cultural Domination}

The vehicle of cultural oppression designed to strangle traditional identity became a tribal instrument for resistance, such as the formal councils following through on "the need... to make decisions concerning the use of resources or the filing of claims against the government..." (Deloria and Lytle 1983:98). The Interior Department, now formally aligned with the Sioux tribal governments, supported the survivors position that the military wantonly massacred them, by providing testimony in the 1938 Wounded Knee Reparations Hearings against the War Dept.. That occurred even though the government feared continuing resistance through filing grievances against treaty violations, landtakings and BIA injustices, and the Lakota traditionals feared that a "puppet government" would disallow those claims. Again, identity was linked to legitimacy.

Even formal organizations such as the NCAI, working within the American systems of national justice and congressional action, provided the national leadership and networking necessary to resist further encroachment, and develop legitimate forums from which to stand for important cross-national Indian interests, and the protests necessary to fight ongoing cultural domination (Prucha, 1984:350). Thus multiple nuclei of resistance arose out of differing forms of identity - traditional, modern, tribal, political and even historic "national" social constructs.

Struggles between Native Nations like the Lakota and American capitalism is evidenced in contemporary corporate influence and takeovers on Indian reservations within the United States. The envelopment and attempted incorporation of the Lakota continued 
corporate power and natural resource exploitation depended on sovereignty struggles against corporate power structures ensconced in U.S. social institutions. Each level of social change allowed resistance. Current"Sioux" reservations and jurisdictional issues are demonstrated with examples of a Lakota "Nation" in conflict with corporate powers over the following resources: farming and ranching, mining, gaming, urbanization, fishing, land-tenure disposal, water and mineral Rights. Issues of taxation are found intertwined with the U.S. nation-state and a panoply of corporate interests, as exemplified in the Lakota-Sioux in the Dakotas. The maintenance of traditional identities allowed a cultural foundation for the modern, activist-oriented Lakota and related Indian groups to launch successful resistance against external (U.S.) and internal (IRA Councils) domination. The following chart reflects the growth of these resistance movements and their identities against changing U.S. policies of assimilation, suppression, and negotiation in the 20 th century.

\section{Fig. 3 :}

[Page 281]

Journal of World-Systems Research

\section{U.S. INDIAN POLICY and LAKOTA RESISTANCE with Direct Influence on Identity}

\section{U. S. American Indian Policy}

1890 's Indian Boarding and Day Schools Primary goal of "killing the Indian" within education for many Lakota children

1910 Sioux Land cedings, by county Intentional breakup of tiyospaye relations of communities with the land

1924 Citizenship Act (Burke Act 1906) conferred citizenship on all Lakota assimilation strategy against nationhood

1934 Indian Reorganization Act formulated American electoral systems on Lakota reservation cultures

1953 Temination Policy, P.L. 280

Urban Relocation Program attempts alienation of Lakota from reservation life

1958 Pick Sloan Missouri Plan 37 breakup of the riverine communities and subsistence family economic patterns

1968 Indian Civil Rights Act individual opportunity laws opened

1972 Indian Education Act 38

1974 U.S. v. Con. Wounded Knee Cases 39 more Indian input with U.S. justice

1975 Indian Self-Determination (Ed) Act 40 1978 Indian Child Welfare Act 41 American Indian Religious Freedom, accorded Lakota same "freedoms" as U.S.

1980 U.S. v. Sioux Nation of Indians 42

\section{Lakota Ovate - Resistance}

1911 Society of American Indians formed Lakota organize cultural and treaty protection for Native peoples and nations

1922 Sioux tribes initiate Black Hills claim resisting land encroachment and Lakota spirituality with sacred lands

1938 Wounded Knee Reparations Hearings survivors from Ghost Dance killings testify Congress on human rights violations

1946 Resistance to "emancipation" bills Lakota refuse tribal alienation with claims to traditional identities and treaties

1959 Opposition to Missouri Dam sites Standing Rock Natives oppose land-takings and destruction of river habitat

1965 SunDances appear in public underground spiritual ceremonies actively practiced in cultural restoration

1969 ('64) Alcatraz occupied (1868 treaty) combined Natives fight for rights

1972 Trail of Broken Treaties, (BIA)

1973 Taking of Wounded Knee, Pine Ridge symbolic and real acts of resistance

1974 "Sioux Treaty Hearing" Int'l Council

1976 AIM struggle, FBI Killings Lakota and "urban Indian" identity asserts historic rights of Native Nations

1978 American Indian Religious Freedom43 
treaty rights between "nations" 1987 BIA (Swimmer) 638 Tribal Contracts 1990 Repatriation Act (museums, graves) Indian remains/artifacts returned
Tribal Colleges, Indian Child Welfare 1987 Black Hills and Traditionals - Oahe44 1988 Sovereignty Movements revived 45 1990 Wounded Knee Riders \& memorials

[Page 283]

Journal of World-Systems Research

Thus we see that the 20th century began with a completely new set of relationships between the dominating forces of the U.S. American society, and the subordinated peoples, Lakota traditionals, progressives, nationalist activists and all the other identity constructions. Policies clearly meant to perform cultural domination or incorporation thru coercive assimilation, were met with resistance and adaptation strategies by all of the identity groups of the Lakota. Three major examples, listed in the above chart, are the U.S. Indian policies of the 1934 Indian Reorganization Act formalizing tribal councils, the 1954 Termination Policy/ Relocation Program moving rural Natives into urban areas, and the 1972 and 1975 Indian Education Acts providing Native control mechanism in determining schools on reservations. Each set of initiatives resulted in counteract responses strengthening rather than weakening traditional Lakota relationships. Although often corrupt and destabilizing, the tribal councils allowed direct Lakota involvement with governance of their reservation "Tribe" or Nation (Deloria and Lytle, 1984) (Biolsi, 1992), strengthening family tiyospaye networks, linkages with traditionals and cultural survival. Even though cultural solidarity was reduced when many Lakota were relocated, new urban networks and "pan-Indian" resistance groups were formed with strong ties to reservation cultures (Fixico, 1986) (Cornell, 1988) (Fenelon, forthcoming). And even though complexities and poor school conditions were rife with Indian Education programs, curriculum and instructional changes were introduced that brought up a new generation of Native children without the oppressive identity definitions inculcated by the dominant society's education (Locust, 1992) (Fenelon, 1991).

Social conditions related to dependency and underdevelopment were outgrowths of the policies that targeted Lakota traditional identities and their claims to sovereignty (Ortiz, 1984). Resistance hardened with these cultural identity groups, relying on oral histories to informally track reservation hardships and U.S. Indian policy to the conflicts over attempted incorporation, conquest and domination of the Lakota.

One traditional elder, having lived his entire life near Cannonball on Standing Rock, succinctly described the historical relationships with present-day realities:

"B.I.A. always had it in for Standing Rock. Because of Sitting Bull. They pass us by... They think...the fight over the Black Hills. We knocked their flag down... Seven years we talked, many delays. Lots of promises. Electricity, water, fuel. New land, irrigation... Nothing... That is why we call it the Taken Land'." (Henry Swift Horse, 1987.46)

The "Taken Land" Swift Horse is referring to covers much of the Missouri riverine valleys and its tributaries on Standing Rock and Cheyenne River reservations in North and South Dakota, (Lawson, 1982). Vine Deloria, in a preface to Lawson's book 
"Dstmmet lnitisns" states the thans are the single most testruetive ad of polioy in the

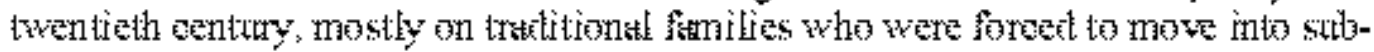

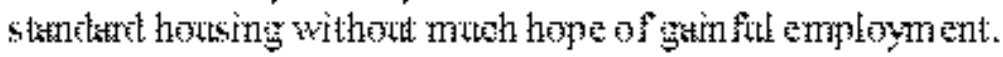

\section{[P:ge 234]}

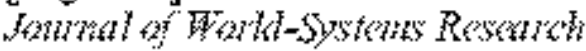

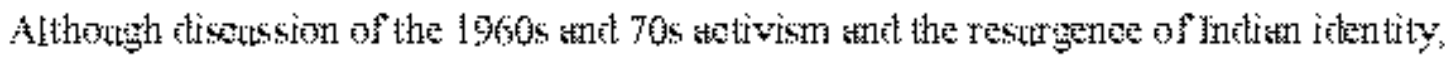

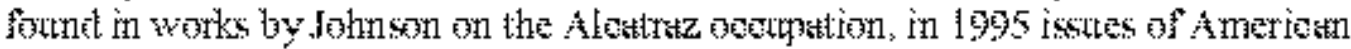

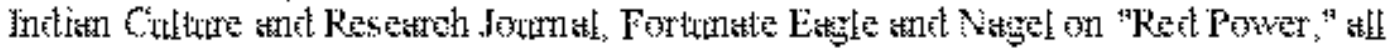

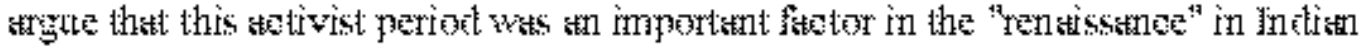

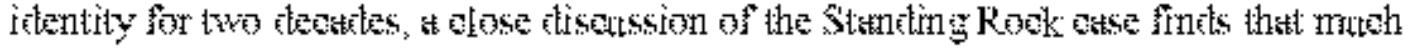

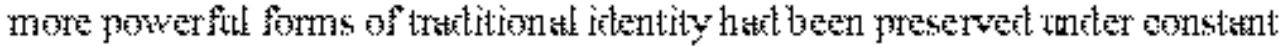

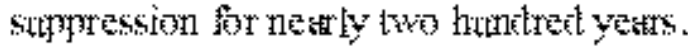

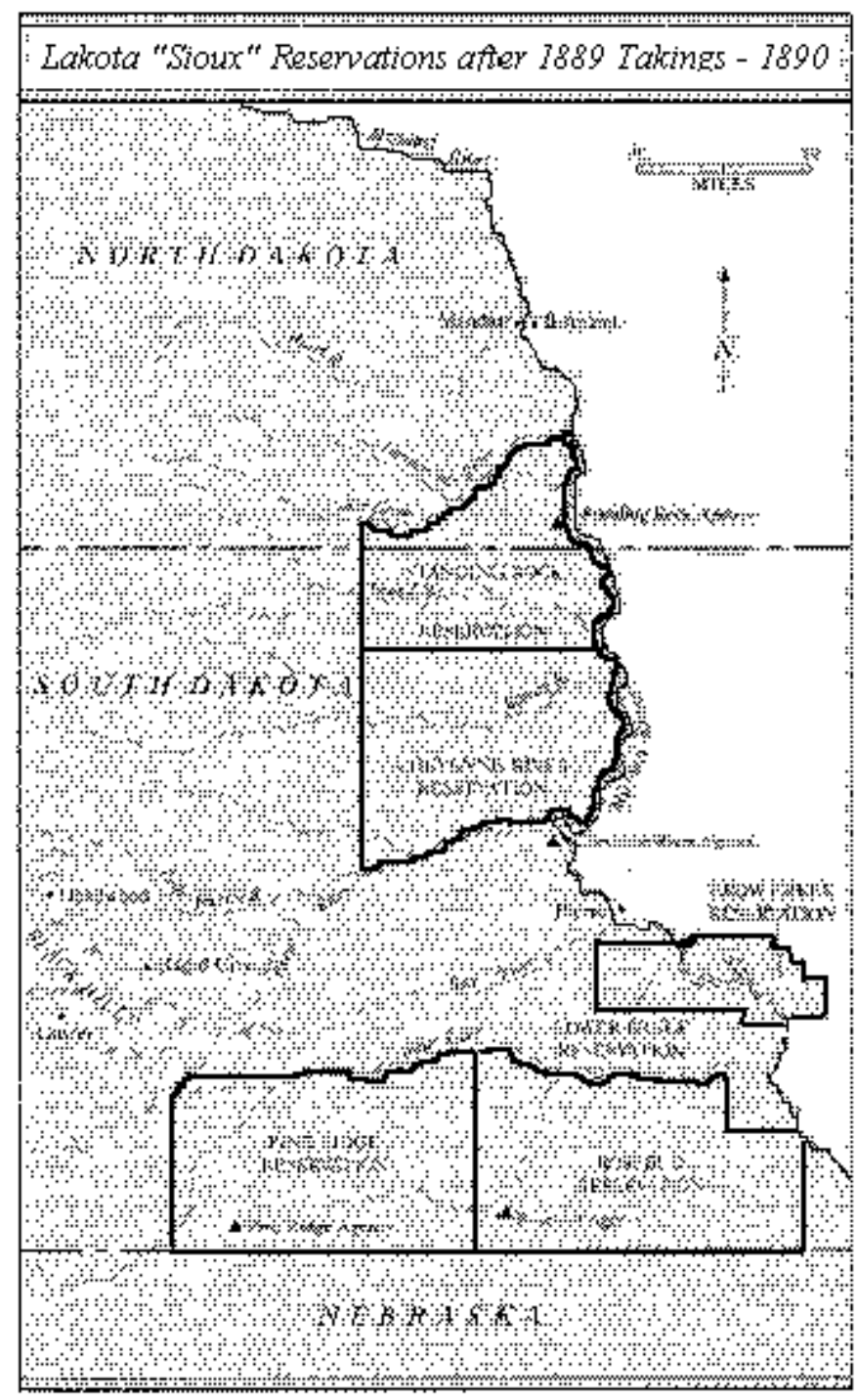




\section{Contemporary Forms of "National" Identity on Standing Rock}

The "Nationalist" Lakota identities, first formed from loose alliances and confederacies, braised in the crucible of armed conflict with the United States, continued to exist and exert influence over traditionalists during the Reservation, Reorganization, Termination and Self-Determination policy periods. The marriage of dual citizenship, cultural survival, resistance, activism and AIM, resurrected the strongest and separatist ideas of Lakota nationalist identities.

While not always comfortable with the most extreme activist groups, the Standing Rock tribal councils never countered traditionalists to the levels experienced at Pine Ridge, reducing direct conflict between opposing ideologies of dealing with state and federal governments.

Because of the diversity of cultural origins and socio-political perspectives on Standing Rock, this section heading of the paper is developed in seven areas. First, the "American Indian Movement and Political Resurgence" of the 1960's and onward, are put into historical context.

"Tribal Councils and the Sioux Indian Reservations" discuss the policy implications of the B.I.A. and governmental efforts to control and direct reservation life. Next, the "American "Indian" Identity forms on Standing Rock" are discussed and listed. Since "The Lakota and The Dakota -- "Tribe" and "Nation"' are part of the make-up of the reservation growing from an Indian Agency, these observations are linked to "SocioPolitical Legitimacy and Constructed Identity" arguments. "Traditional Culture and Coerced Social Change" are presented in terms of resistance ideologies, developed in an "Elder's Statement to the SunDancers at Prairie Island" in the 1990's. Finally, "The Many Faces of Native Identity on Standing Rock" are presented.

\section{American Indian Movement and Political Resurgence}

Reservation, Reorganization, Termination and Relocation policies developed an explosive mixture of historical wrongs, systematic inequalities, stunted political participation and linkages with urban unrest and ethnic resistance groups across the nation.

[Page 285]

Journal of World-Systems Research

Some young Natives experienced injustices, thinking of themselves as American "citizens," and yet also claimed rights to representation as "Indians." By the 1960's, these forces, with an eye toward the Civil Rights movement in the South, were arrayed across a spectrum strong enough to challenge the dominant society's institutions. In 1961, with Lakota-Dakota numbers, the American Indian Chicago Conference convened a collaboration of academics, policy-makers and Indian delegates from over ninety tribes, resulting in a formal Declaration of Indian Purpose. 
Internecine resistance struggles on the Sioux reservations, with an increased presence and activity in congressional legislation and so-called pan-Indian movements for resisting domination, ignited powerful issues of "Lakota Oyate" sovereignty and spirituality tied to claims for the Black Hills and the 1868 treaty with the "Sioux Nation of Indians". Within a few years, ceremonies existing underground for over seventy years began to surface, including the socially cohesive and spiritually powerful SunDance of the Lakota.

About 1965 limited SunDances appeared in "public" places within Sioux Indian country, along with the resurrected ceremonies came renewed awaren ess of traditional life and spirituality. SunDances were essential acts of resistance - to law because it was still illegal, to federal policy because the SunDance was suppressed in the previous century, and to BIA agents it was the quintessential symbol of community solidarity of traditional Lakota culture (McGaa, 1990).

Evidence that the SunDances had been conducted on very small scales among the Lakota traditional groups ("bands" and tribes), includes pictorial proof on Standing Rock (1919, 1924, 1930's), Rosebud (1930's, 1940's), and Pine Ridge (1920's, 1930's); such as Hunkpapa pictures taken at Little Eagle, South Dakota side of Standing Rock, with the SunDance pole, dancers with eagle whistles, and signs of sacred spiritual ceremonies only found in a SunDance. 47 Therefore resistance through maintenance of cultural identity resurfaced with political overtones.

By 1968 , the Civil Rights Act included some specific features for Indians, with limitations addressed by Indian leaders, such as constitutional prohibition against "establishment of religion" obstructing the practicing theocracies of some Indian Nations, potentially complicating Lakota religious practices including the SunDance (Wunder, 1994). The Indian Civil Rights Act "had a mixed reception" precisely because it intended "to bring Indian tribal governments within the constitutional framework of the United States." (Prucha, 1984:363) Indian leaders foresaw danger to sovereignty with unrestricted inclusion, but welcomed repeal of P.L.280 state jurisdiction.48

[Page 286]

Journal of World-Systems Research

In 1969, Indians of All Tribes (IAT), headed by Oaks, a Mohawk, and Trudell, a Dakota, re-occupied Alcatraz island by claiming 1868 treaty and 1882 statutes, noted in an earlier Sioux attempt in 1964. The pan-Indian activists combined symbolic and physical acts of resistance, electrifying the nation, the media, and Native Americans. In response to momentum from renewed activity in Civil Rights, the American Indian Movement was formed in an urban atmosphere in the Twin Cities, historical heartland of Wo-Dakota Oyate, and ancient homelands of their Lakota allies, with the other "Sioux Nation of Indians" dispersed outside Minnesota.

In 1972 the Trail of Broken Treaties was initiated on a national level of struggle, pitting the BIA against combined groups including AIM and IAT. The 1868 treaty claim figured heavily in the decision to mobilize Indian activists throughout the nation. History struck 
home in 1973, for Lakota on Pine Ridge with the re-taking and "occupation" of Wounded Knee, as resistance against the imposed tribal government, at the 1890 genocidal killings site of Lakota traditionals. Young Bear remembers that after the Trail of Broken Treaties, "the government sent its people" telling "they are going to take your agency" and suddenly " in Pine Ridge we had armed vigilante squads -- goon squads -- fortified up on top of the BIA buildings," (1994:148-49), who "started harassing people." Young Bear was involved in demonstrations at Rapid City, leading to arrest and injunction because he was a "national AIM leader", that he attributes to his Porcupine Singers' drum support of AIM, so "maybe singing stirring songs is dangerous to people in power".49

Meetings had women exhorting the traditional leaders to "stand up and change things".50 Wounded Knee had symbiotic qualities of a resistance to domination and a powerful spirituality and harkening to the sovereignty of Lakota Oyate, reflected in Young Bear's recollection of the decision and preparation as Akitchita, Tokala "warrior spirit":

"Fools Crow got up and prayed. Then he said "The people need you, are you willing to give up your lives?" Everybody said hau -- that means yes. Fools Crow then said, "What we'll do is take over Wounded Knee store and church and challenge the government to reenact the Wounded Knee Massacre of 1890. Come in and kill us!" A lot of those old men got up and said "Yes, let's do it. It should be done that way... ...they'll really react and put you in prison or kill you." Fools Crow said "Waktapo, ogna wiconi ehpeya kiyapi kte lo." (Beware, you might have to give up your life.) They all agreed and they prayed again. Somebody had a sacred pipe, so they all smoked." (Young Bear, 1994:149-155)51

[Page 287]

Joumal of World-Systems Research

Lakota traditionals and AIM leaders took and defended Wounded Knee for two months, under constant fire from U.S. government forces. The U.S. called the negotiations a "surrender" and courts arrested the participants. However, throughout the occupation of Wounded Knee II (1973) traditionals showed support. "The people who believed in treaties or lived the traditional way of life supported Wounded Knee II..." (Young Bear, 1994:154)

Even our own district members were on both sides of the conflict because some of them were getting paid as BIA police officers, deputies or goons. It's an old colonial technique to use our own people as police against us. These goons were mostly mixed -bloods who got fifteen or twenty dollars an hour, and they went around beating up people and shooting at them... (even) more than the military. (Young Bear, 1994)

\section{Tribal Councils and the Sioux Indian Reservations}

Conflict over full-blood traditionals "old-dealers" maintaining claim to 1868 Black Hills, opposing the more mixed-blood progressives "new-dealers" pushing for assimilative governance, was a central feature of government intervention in the conflicts on Pine Ridge, and replicated divisions on Standing Rock. Although the tribal councils were 
without question oppressing some of their own people, for and by whom they had been ostensibly elected and therefore represented, they were recognized by the United States government as "legitimate" and "true". Certainly, many of them considered their own positions in that light.52

These issues come to a head -- historic repression, the resurrection of banned ceremonies, using the pipe as a treaty seal in personal faith, the ancient Akichita oath to defend "the people" (Oyate), local and regional resistance to cultural domination, and expression of traditional Lakota spirituality -- in events directly preceding the re-taking of Wounded Knee (Young Bear, 1994). Afterwards, the conflict continued with the involvement of AIM, increasing repression by tribal GOON squads, and deepening coordin ation by the United States, notably the FBI.53

Socio-political resistance forces organized an International Treaty Council in June, 1974, held with support from the Standing Rock council, with many Indian Nations. Language from the "Declaration of Continuing Independence By the First International Indian Treaty Council at Standing Rock Indian Country," states the general thinking of these Native resistance forces:

We the sovereign Native Peoples charge the United States with gross violations of our International Treaties. Two of the thousands of violations that can be cited are the "wrongfully taking" of the Black Hills from the Great Sioux Nation in 1877, this sacred land belonging to the Great Sioux Nation under the Fort Laramie Treaty of 1868 .

[Page 288]

Joumal of World-Systems Research

We condemn the United States of American for its gross violation of the 1868 Fort Laramie Treaty in militarily surrounding, killing, and starving the citizens of the Independent Oglala Nation into exile... (and) for its genocidal practices against the sovereign Native Nations; most recently illustrated by Wounded Knee 1973 and the continued refusal to sign the United Nations 1948 Treaty on Genocide.54

The battle had been joined - Indian movement "activists" aligned with traditionals and other Lakota on the reservations against organs and institutions of the United States government, including tribal governments such as at Pine Ridge. In an interesting assumption of the dominant society's language within its unilateral legis lation, the International Treaty Council listed the pertinent acts and judicial decisions:

We reject all executive orders, legislative acts and judicial decisions of the United States related to Native Nations since 1871 , when the United States unilaterally suspended treaty-making relations with the Native Nations. This includes, but is not limited to, the Major Crimes Act, the General Allotment Act, the Citizenship Act of 1924, the Indian Reorganization Act of 1934, the Indian Claims Commission Act, Public Law 280 and the Termination Act. 
In 1974, the federal government brought U.S. v. Consolidated Wounded Knee Cases 55 forward in Lincoln, Nebraska, known to its Lakota participants as the "Sioux Treaty Hearing" because the defendants from Wounded Knee II claimed non-jurisdiction due to the 1868 Treaty, responding with claims to Lakota cultural and socio-political sovereignty, and thereby identity, including:

1. "...this Treaty (1868) was made with a Nation, the U.S. and the Sioux Nation... but from the oral history... the Sioux people never gave up anything as far as their land, their sovereignty, or as a people, or even our culture..." (Young Bear)

2. "My (Treaty) understanding is... the people will govern themselves under the leadership of our Chiefs. Our law and order will be maintained by Sioux people. ... but the U.S.56 forced some Acts... opening our land and invasion of the white people. (Chasing Hawk)

3. "Oral history of the Treaty as I learned from my elders pertains to a beautiful word in our language, Wohlakota, which means peace between two nations, sovereign nations, Milahanskan which means the U.S. and sovereign Sioux Nation of our Lakota." (Gabe)

4. "The 1868 Treaty described a boundary which the United States was not to enter under any circumstances. The Lakota people would continue their traditional way of life and be a self-governing people like any other country." (Spotted Horse)

[Page 289]

Journal of World-Systems Research

5. "The Treaty was signed by the Lakota Nation to stop the war. And the land within the Sioux Nation belongs to the Sioux and no white man will come into our land. The Sioux Nation will govern itself. The nation will live under the Pipe. (Kills Enemy)

6. "Before the Sioux signed they used the Pipe...the peace was to be forever. The U.S. made their promise... told about their Bible...Two nations made agreement." (He Crow)

The re-taking of Wounded Knee had serious side-effects for the struggle over ideological rights toward claims for "sovereignty" and cultural integrity alien to dominant American society -- it focussed the engines of governmental repression on Pine Ridge and the Sioux reservations, pitting tribal councils and the BIA against their own people and "wards" in trust. The result was deep entrenchment of the American Indian Movement (Matthiessen, 1991). Two FBI agents were killed when they stormed into a Pine Ridge AIM compound. A new realm of conflict ensued, where enlightened policy makers were thwarted by FBI "counter-insurgency" tactics.

Lakota identity on the "Sioux" reservations was complicated by political fragmentation, strong differentiation between "full-bloods" and more assimilated "mixed-bloods", involvement with tribal government, and generational differences with new activism. Families were sometimes set against each other, with Crow Dog and Spotted Tail on the 
Rosebud (Erdoes and Crow Dog, 1995) or Sitting Bull and Gall on Standing Rock, or could be divided among themselves as with some McLaughlins descended from the first Indian Agent. Similarly, veterans from World War II often maintained different loyalties than Vietnam veterans, reflecting the larger society.

\section{American "Indian" Identity forms on Standing Rock}

The U.S. Bureau of Indian Affairs enrolls American Indians as the "Standing Rock Sioux" depending on a blood quantum based on "rolls" made after the Treaty of 1868 . These rolls include Hunkpapa Lakota, Sihasapa Lakota, and Yanktonai Dakota people. Additionally, many individuals claim these and other Native American identities related to Standing Rock, either as a reservation or an historical cultural group with nation-like underpinnings. The socio-political history of Standing Rock reveals, however, that it is entirely constructed by the United States BIA as an Indian Agency, chronologically followed by reservation status, a tribal council, and finally a very limited autonomy resulting in claims to "nation" status.

[Page 290]

\section{Journal of World-Systems Research}

Therefore, the Standing Rock "Sioux" designation comes from either Lakota or Dakota cultural backgrounds along with claims to the respective "oyate" or nation status. Additionally, individuals from either group may or may not be enrolled, have strong connections with the tribal government, know their own language or be involved in traditional social and spiritual practices. "Full-bloods" may be on the tribal council or work in agency offices and be called "BIA Indians" just as "mixed-bloods" may embrace the renewed "religious" practices and know traditional life. These terms have become identity markers that do not necessarily reflect their true origins.

A wide diversity of identities was unleashed during interviews, such as a "pipecarrier"57 following Lakota "traditional ways"; a "traditional" woman "relocated to (the city)" and cross-identified with urban and reservation people; a "full-blood" who was "strong because of (her) activism" noted by non-Indians58; and an "urban Indian" with a need "to maintain connection" to her home community.5960

These statements reflect the perspectives that contemporary American Indians have:

1. "I'm a Sioux woman, Yanktonai, and it (the group) should be called the Sioux club. I've lived here for almost forty years, so this is my home, but I am from Standing Rock, and so is my daughter... We speak Dakota, and of course English... Some of these people don't even know where they are from, and so they're from nowhere..." (Earth-Powers, 1995)

2. "I am from (a particular Lakota) Sioux reservation - I don't like that word Sioux, but for means of identification I suppose it's OK. ...that's what I consider home, although I'm living out here, I guess I feel expatriated..." (Yonder, 1994) 
Sioux is not a traditional word, for as the speaker says it was "imposed by the oppressors (BIA) as a tribal identification" label, even as the older speaker prefers the word as "nearly traditional", knowing its origins. The use of "home" demonstrates cultural linkage, as does "expatriated".

3. "I felt it was an insult to the wisdom of my ancestors that the knowledge passed on to me should be valued so lowly... When I began teaching, I was amazed how many (Indian people) didn't have any (knowledge of their) background as a people." (Defender, 1993)

[Page 291]

Journal of World-Systems Research 4. "When I first came to (the city) I thought 'Good I can relax here' because I had come from South Dakota where you can cut discrimination with a knife it's so thick. But that's not true. Here you find discrimination trying to get our needs met with city and state systems, because the Indian community doesn't have group strength." (Blue Weather, 1992)

5. "When you get cornered, boxed in, with nowhere to go, and your people are attacked... you resist... They take your land, your traditional ways, and then they want to start education their way, and all that is a continuation of their system. It's hard to be an Indian. They embargo your people, your ways, your nationhood. I had to expose this system that is used to destroy us, what is why I talked to the U.N., because we are a nation... They say "we acquired the land, we conquered this land, but we, the Sioux nation were never conquered. We will take our sovereignty..." (Grass-man, 1993)

Thus identity is a very transportable cultural baggage, whether as "Sioux" or "Lakota," indicating both resistance and ac ceptance as a Native American Indian. One traditional elder visiting the city talked about the importance of traditions, ending with:

6. "...when you know, you learn your language, your traditional ways... your whole outlook on life will change, your whole value system will change - you will be proud when someone calls you a traditional - you will become proud of your identity, and you will see the beauty of life, ,,, and walk the good road." (Big-Horse, 1993)

The importance of an "Indian" identity as foundational to all else, as well as complex changes in Lakota identity itself, underscores lack of a single identity marker for Standing Rock "tribal members." In fact, tribal membership itself is contested.

7. "(The) colonial powers, coming in and re-naming us, ... naming us... (the)...military never gave the people, my grandmother, then chance to go back to their emergent, sacred places... (to re-new their identity)... People have been separated from their emergent places, and are not educated in their language." (Defender-Wilson, 1996)

Thus "traditionals" are not always aligned closely with either "activists" or "tribal" governance. The re-naming process, along with amalgamated groups on Standing Rock, have resulted in great ambiguity of identity that can emanate or relate to a number of identity markers, including "Lakota Traditional Native American," "Dakota Tribal 
Member Sioux Indigenous," "Hunkpapa Assimilated Indian Activist," or "Yanktonai Agency or BIA Tribe Separatist."

[Page 292]

Journal of World-Systems Research

On or near Standing Rock -- known as an Indian reservation, a "tribe" and now "Nation" - any person of indigenous descent may or may not use any combination of the above identities. Both Dakota and Lakota people may work for the Bureau of Indi an Affairs or the tribal council; they may have mixed "blood" with other "Sioux", other Indian tribes or nations, or non-Indians; they may see the Lakota Nation as politically desirable or want better relations under the states; they may have been or still are AIM separatists, or they may see their U.S. military veteran status supremely important; they may want to be identified as "Indian", "Sioux", "Lakota or Dakota", "Indigenous", "Native American", "Hunkpapa or Yanktonai" or just as an "American".

\section{The Lakota and The Dakota -- "Tribe" and "Nation"}

The Black Hills claim was reinserted in the judiciary system shortly after Wounded Knee, leading to a favorable 1980 Court of Claims decision in United States v. Sioux Nation of Indians with a substantial Black Hills settlement,61 notably without land restitution, achieved with this testimony from Frank Fools Crow:62

We understand that over 80 percent of the Black Hills is still under the control of the United States. This must be immediately returned to the Lakota people and negotiations must begin for the remainder... Oglala Lakota have always been caretakers of the Black Hills and it is appropriate that I have been allowed to talk here today defending the sale of these hills for my people and other Lakota people. (Fools Crow and Kills Enemy, 1976)

Important symbolic victories of these struggles led to the 1978 American Indian Religious Freedom Act. SunDances among rural pockets of Lakota, as well as other Plains Indians people, were restored for community participation. Lakota spiritual leaders supported traditional values, bringing renewed respect to the sacred pipes and purification ceremonies. Ever so gradually, concepts of "oyate" moved from the spiritual to the sociopolitical realms.

However, whereas the Lakota, Dakota and the separate otonwepi, Hunkpapa or Sihasapa, have historical claims to oyate traditional identity, Standing Rock has no such cultural legitimacy.

Recently traditional teachers of the Dakota people from the Standing Rock (Indian) Reservation, reviewed a pre-publication titled "History and Culture of the Standing Rock Oyate" coordinated by the state office of Indian Education under the North Dakota Department of Public Instruction. 
[Page 293]

Joumal of World-Systems Research

However, the term oyate is not appropriate to use with the Standing Rock (Indian Reservation) which is a U.S. government constructed socio-political entity combined of Dakota and Lakota people as an instrument of internal colonialism (Hall, 1989) (Snipp, 1986) (Hechter, 1975).

Both the anthropological literature (Green, 1995) and sociological (see Champagne, 1995) studies are quite clear on these points concerning political versus traditional forms of identity. Oyate, loosely translated to mean "the people" or generally glossed into a non-western "nation" constructed of a large grouping of related or closely allied people usually living in close proximity, requires traditional representations. Without such historical underpinnings, the term legitimates contemporary power and political structures that all originate from United States Indian Policy, and not from traditional forms of identity such as the term indicates. Moreover, the identified traditional groupings, each with a tentative claim to usage of the term "oyate" (see Walker, 1917), -the Sihasapa and Hunkpapa (Lakota), along with the Yanktonai (Dakota), were literally forced unto reservation boundaries that grew out of U.S. government Indian agencies whittled down by U.S. military forces acting out treaty infractions of the United States government in many forms. Therefore, using techniques from comparative / historical methods, both the "nation" and "tribe" terms are problematic, and oyate terminology is mis-applied.

As Vine Deloria Jr. demonstrates in "Red Earth, White Lies" (1995), the primary danger with applying such terms and their Euro-American paradigms, is that they perpetuate themselves. The state document commits such errors on multiple occasions, so instead of discussing opposing theories of both Dakota and Lakota origins, especially that of social science against traditionals, the work reports that the Ihanktonwana "moved onto the prairie" and "displaced these tribes" with "some bands adopted" (of) "horticultural techniques" that infer hunting and gathering.

Many social analysts and almost all traditionals now refute the "migration" hypothesis, instead lending credence to economic incorporation of semi-periphery peoples in advance of an expanding world system driven by capitalist states (sociologists), and push-pull movement factors, with so-called horticultural and food preservation practices already well-established (Wolf, 1983), or its less accepted corollary of traditional notions (possibly creation myths) of an origin place, with geographic and environmental features describing formation of an oyate and its homelands, (Goodman, 1992) (Young Bear, 1995). In fact, recent gatherings and traditional conferences have recorded challenges to these Euro-American induced identity formations (Jaimes, 1992), such as the Lakota Summit Declaration in August of 1993 (also see Indian Country Today, Lakota Times for multiple entries since 1993).

[Page 294]

Journal of World-Systems Research 
Both contested identities of "tribe" versus "nation" have ethnographic identity problems. Tribal councils, originally set up and run by the BIA, now claim "national" political constructs, such as with the Standing Rock Nation. Ethno-methodology questions the source of legitimation and the "ethnic re-organization" (Snipp and Nagel, 1992) of a constructed form of identity.

\section{Socio-Political Legitimacy and Constructed Identity}

"Tiwa heyon ka-pi... There's Lesser Bear's Lodge, what you call Fort Ransom since 1868, pyramid hill... .... an emergent place of the Northern Dakota... Greater Bear's Lodge, known as Devil's Lake... The Cheyenne, each people has their own place of emergence... Hawk's Nest... We say 'maka-pi wakan,' -- only the earth lasts forever... (Our) identity is the spirit... (But instead) you have somebody re-identify us... Indian time, it doesn't mean being late, it means there is no clear-cut past, present, future. Our traditions, (identity)... Even now, we use (other terms)... Hunkpapa, really comes from Humupatina, referring to Humu-pa-paha, what we know as Devil's Tower..."(Defender-Wilson, 1996)

Cultural legitimation for traditional identity, such as is claimed for oyate or nation terms, would describe the above origins for Yanktonai Dakota and Hunkpapa Lakota on Standing Rock. Weber's sources of authority, similar to socio-cultural legitimation, include the "bureaucratic," such as the BIA, the "charismatic," such as Sitting Bull enjoyed with Lakota, and the "traditional" meaning an extension of traditions. Thus "nation" and "tribe" result from bureaucratic authority, considering the history of Standing Rock as an agency and an Indian reservation. Tribe however, can derive from traditional(s) worldviews, when it corresponds to one of the groups listed above. Tribal councils, without traditional authority, are therefore assimilated forms of governance, although Deloria and Lytle (1983) distinguish between those that replicate or replace traditional social structures from those that act as agency "puppet governments" for the United States. Deloria even finds that tribal councils can be the first real "nation" governance.

These tribal issues are reflected in studies of the "Flathead" Indians by O'Nell (1996), wherein enrollment by a mixed-blood tribal member whose siblings cannot or are not enrolled, becomes a primary means of identification in some circles, and yet is left out altogether in others. The same subjects appear to relate to being "really Indian" as traditional in language, life-ways, and spirituality, which they find impossible in "contemporary" reservation life. The cultural "test" for being traditional is based on historical notions and modern stereotypes of Indian identity.

[Page 295]

\section{Journal of World-Systems Research}

Similarly on Standing Rock, for those of both Dakota and Lakota background, identity forms are expressed interchangeably in all of the political, cultural, and social interaction spheres, partly depending on the interlocutors and their perceived level of "Indian-ness" on the reservation. The amalgamated constructed identities relating to being a "Standing 
Rock Sioux" are founded within opposing socio-political identities based on whether legitimation comes from governmental entities, either U.S. or tribal, or cultural notions, either traditional or contemporary.

When "sovereignty" extends to government contrived Sioux Indian reservations, but is withheld from the "Sioux Nation of Indians" represented by the Teton-Lakota people, identity and its political constructs become internalized modes of divisive domination. Defender describes "tribes" that are calling themselves "nations" when they exist in tribal councils "controlled" by the government, with enrollment issues that lead people to say "I am Standing Rock Sioux," when that is "a super-imposed identity from the outside..."

Considering Clifford's observations (1988, pg.339) about the "long, relational struggle to maintain and recreate identities.." of the Mashpee Wampanoag over three and a half centuries, the Lakota who initiated the Bear Butte Councils and attempted formation of the Lakota Nation, may simply be placing more steps in a process to preserve and protect external awareness of the Lakota as a sovereign and independent people.

"They (the government) 'enrolls' us, to control us, which I compare to South Africa... ...many will say, 'Where's your ID card?' (their BIA enrollment card)... ... and I will not have one -- I will not have a number, or be registered by the government... 63

As Defender-Wilson (1996) states above, many contemporary "traditionals" are fully aware that enrollment leads to effective bureaucratic control over cultural identity and sources of authority. Similarly, she observes that blood quantum as a test for tribal enrollment, including by councils, becomes passed on by indigenous people themselves in struggles for recognition.

Another thing everyone asks, is 'How much Indian are you?'... I will not have my identity determined by such questions... I've always dislike the word 'tribe'... Now they say that the tribe is sovereign. I think that is (also) used as a form of control..."

[Page 296]

Journal of World-Systems Research

\section{Traditional Culture and coerced Social Change}

"Our elders speak of the first times that our people came in contact with the forces of the United States Government which they are presently known by. Our people were for the family. They did not destroy their language, their culture, or their people. They only told the intruders one thing -- try and live the ways, go back and leave us alone. That was not a very hard request, but they would not leave us alone. Yet today we are still repeating the same message." (Lewis Bad Wound, testimony at "Sioux Treaty Hearing" in 1974)64

Forms of traditional identity have changed under coercion of U.S. Indian policy. Lawson, (1982:198), finds that "by altering their traditional environment, natural resources, social patterns, and means of livelihood, Pick-Sloan (dams on the Missouri) has made sure that 
the Sioux tribes of the Missouri River have considerably less of their past to hang on to..." Standing Rock traditional people see that environmental destruction as directly connected to government domination

"My grandfather always said, when a cow gives birth to a calf, who is gonna take care of it? The mother has to take care. But we have lost that, they have taken our mothers... So how do we keep our society?... I do not recognize the IRA (1934) government, it is an act of Congress -- it is a violation of our treaty, our way of life. That has to be recognized!... Sovereignty, according to U.S. law, is accorded by the Congress... But that is not how I understand it. We have always had sovereignty. It is not a 'given sovereignty'." (Grassman, 1993)

The long-awaited assimilation, introduced and directed by institutional arms of the U.S., never occurred in terms of cultural identity. Ever since the armed struggles and AIM presence, resistance to modernizing forces off the reservation actually increased, as did involvement with traditional cultural practices that were associated with it.

(After 1973)... I saw lots of signs of a growing positive identity among our young people. I saw lots of young boys and young men growing their hair long again and identifying themselves as Indian. Even women started wearing their hair long again and were now fasting and SunDancing. They had many of those AIM leaders and those who took a stand with them to look up to as models. It was a time of real positive identity. (Young Bear, 1994:157)

One elder, speaking at the end of SunDance ceremonies in 1994, first spoke of his home, and its relationship to the oceti sakowin (seven councilfires) and his relatives. Then he identified the Lakota origin place and the people as "oyate," before identifying his cultural authority and the nature of Lakota ceremonial and spiritual life. He demonstrated an indigenous giving of "witness" through oral history and tradition as truth, by presenting a pipe in a sacred manner, to the Dakota and Lakota people assembled in June of 1994 , in recognition of the 1993 M'deWakantowan SunDance held after 150 years of repression.

[Page 297]

Journal of World-Systems Research

(Given by Chief Dave, Lakota spiritual leader... paraphrased into English )65

"Mitakuyepi, My name is (Lakota traditional), my father's and my mother's people were (local tiyospaye), My grandfathers were and always have been of the M'niconjou people, of Lakota speakers and the seven council fires of the "oceti sakowin" including my good relatives here, the M'dw wakantowan Dakota people."

This "Elder's Statement to the SunDancers at Prairie Island"66 perfectly represents all identity constructions and applications of what is known as a Lakota "traditional" -historical references carrying as much weight as his own name and home. The much - 
maligned and often stereotypical ties to the land, and United States attempts to break those ties, makes up his group identity.

"We Lakota, and our relatives here the Dakota, originated from sacred places on earth, according to our sacred traditional knowledge. The Pte Oyate, we as the buffalo people, came out from the earth near the place where the holy winds blow out, very close to the Paha Sapa, the Black Hills, always known to us as the sacred "He Sapa". We know these things as the Wasicu know their origin place, and so it is..."

Even more powerful for applications of world systems analysis, is the careful oral recounting of the conquest, injustices, and suppression of the Lakota Oyate and the Dakota as an allied nation, translated in a brief account in the endnote 67 . This elderly Lakota spiritual leader, a real "chief," represents the linkage between identity, resistance, and domination.

\section{The Many Faces of Native Identity on Standing Rock - "Elders"}

1. "There are seven campfires, and I am from the Teton, the Hunkpapa, living on the South Dakota side of Standing Rock... I know my language, my ways, and I get visions... We are losing ground, our land, our reservation... I wonder about so many laws on immigrants -- yet we are the forgotten people..." "If you back up a horse, or even a cow, up against a corner, it will fight back -- it will kick you. That is how it is with indigenous people, the Hunkpapa... (we) went in 1973 with our 97 Indian nations..." (Renfrew Big Horse, Lakota, October, 1993) 68

[Page 298]

Joumal of World-Systems Reseurch

Diffusion of spiritual practices is tightly wound up in critical identity issues, which virtually every traditional Lakota leader begins with by identifying their relatives. Assimilation is the enemy in this stratagem of survival, and appropriation of surface level Lakota religious practices, stereotypically and romantically reproduced, is a grave threat. Lakota leaders confront these historical treaties, religion, and indigenous Lakota law.

2. "They are breaking those treaties, by denying us our religion, our own laws, our relationships to the land... My grandfather went to their government, and signed their treaties, to protect our rights... We were free, a free people before those treaties..." (Grass-man interview) "...We fought to protect (our freedom)... The constitution to us, is a cutoff point for Native Americans... The seventh generation is here today, as we, grandfathers, look upon those, who are educated..." (Walking interview, 1993)

Grass-man, Big Horse and Walking, do not deny benefits of formal education, as they note when discussing the issues with my degrees. But they see benefit only in terms of biculturation, not assimilation. Moreover, they view the American constitution and bill of rights as a point of oppression, not freedom as Lakota define it. They poignantly refer to the "seventh generation", stated by Red Cloud and other Native leaders - as the future of 
Lakota children inheriting these traditions. The trails of resistance extend from monetarily poor but spiritually rich reservations, into American cities with dislocated Indians, the federal government, and the United Nations.

3. "We are more and more identifying and living out our lives within the colonial society. Like those who lived (like the agents), and stressing democracy and distribution equally, "when those 638 contracts (for land) were issued, only certain families received them, and you know this is true, (that) they were (all) relatives of the council members." Gradually, we begin to think just about our-selves, and not the people." (Defender, March $7,1995)$

Social change working to dismantle dominating systems is on many levels, - individual, community, national. One activist notes that "community organizing is a way issues are brought to the table of city, state and federal government," but betrays her bias that Indian people have "an almost passive approach to problems, that has its basis in culture." She sees modern society as different from "traditional ways" and that Indian people who grow up without "reference to ...the world-views of the reservation ...adapt the dominant culture's values as their own."

[Page 299]

Journal of World-Systems Research

The identities and resolutions demonstrate these conflicting orientations of love and hate, resistance and assimilation, incorporation and separation, found in differing respons es to questions about attempts to change the Indian community:69 These responses also reflect the differing perspectives from those who continue to live on the reservation, and those whose fortunes have taken them to off-reservation, usually urban areas.

4. "I am sorry I ever served in (the military of) this country, the way they are treating Indian people..." (Grass-man, 1993)

5. "This Indian wants to keep the 'fighting Sioux' name of the football team I played on for the University of North Dakota, as a veteran, and thinks somebody that wants to change that should have to convince the alumni first!" (V. Feton, 1994)

Sovereignty and ethnic identify, in terms of serving one's country and people, are expressed by these World War II veterans. The first speaker, a full-blood living on a reservation, tempers his previously proud service in terms of his more recent experience of discrimination. The second speaker, a mixed-blood living in an urban area, identifies with his military record, college graduation, and business success. Traditionals demonstrate sophisticated awareness of these lived divisions of structural oppression.

6. "Some of the treaties are still being broken, abrogated... As traditional people, we honor all persons, even those who have forked tongues. That has to stop... We must band together... (must work together)." (Renfrew Big Horse, Lakota, October, 1993) 
7. "the system is not right, is corrupt. The B.I.A., the states, our own I.R.A. councils... The state people are so racist toward Indian people, we are the Mississippi of the North... ...We did not grow up with drugs, with gangs, we had our own good value system... I am against these casinos. They destroy our ways of life..." (traditional Dakota elder)

Casinos and economic development are providing intensive social change (Fenelon, 1997) throughout the communities on Standing Rock. It is a process that is welcomed for its income, and considered suspiciously by most of the traditional elders who have observed loss of many traditions and cultural practices over their lifetime. This paper has relied on those traditionals, and elders, as the primary informants on the changing indigenous identities on Standing Rock.

[Page 300]

Journal of World-Systems Research

While it is beyond the purview of this research to consider the myriad short-term effects likely to result from the impact of money, jobs and of greater off-reservation non-Indian traffic, based on the one-hundred fifty years of domination wherein traditional Lakota life has survived, the loss of "Indian" identity seems unlikely. Instead, each succeeding generation will contribute more changes to the complex identities of modern life with traditional culture on Standing Rock. Incorporating the voices of those currently involved with "tribal" leadership, whether political, cultural, economic or spiritual, will further inform the social change processes taking place over the turn of the century.70 


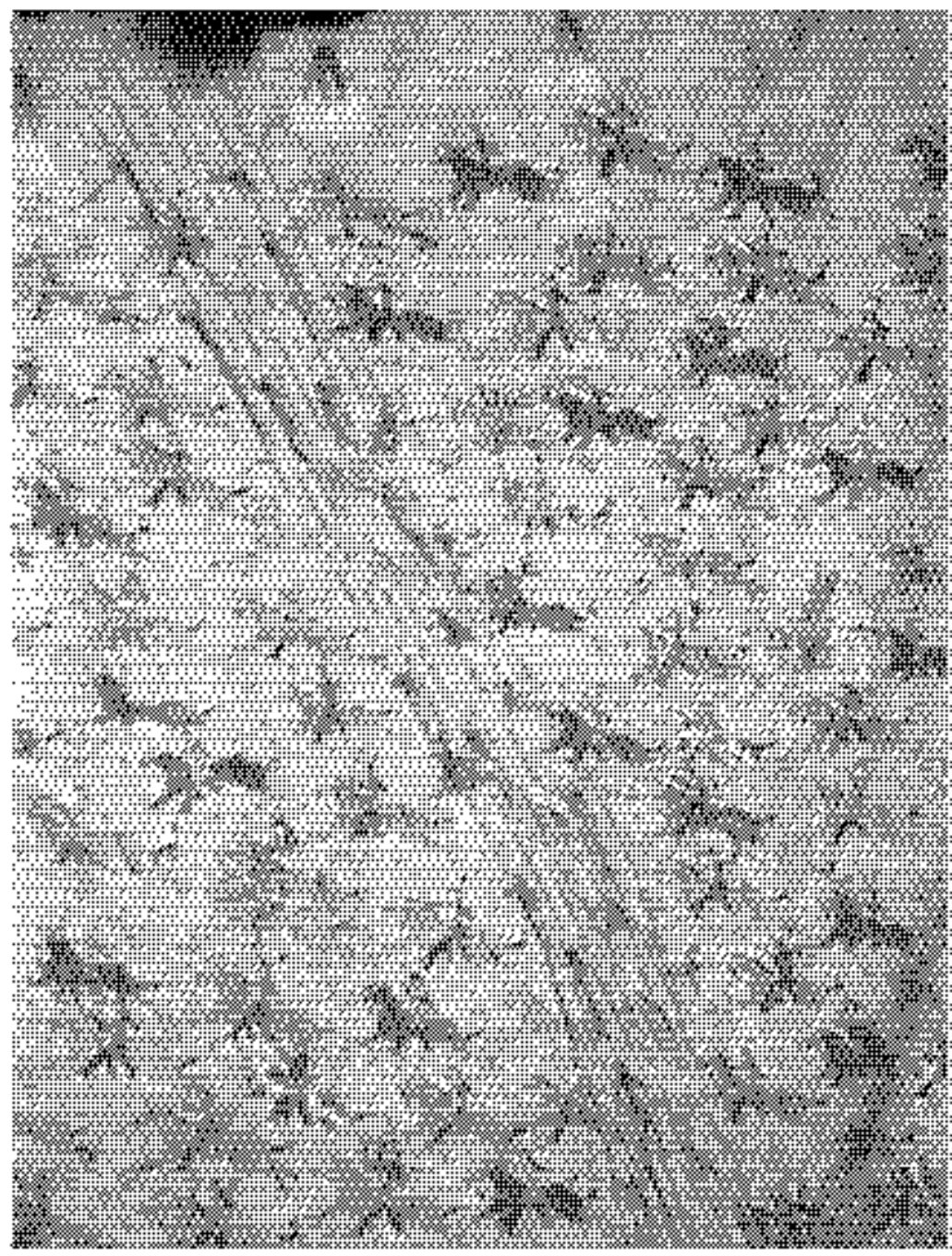

B $6 f f l o t h d$

pommonoms

ond Thdoton

hnothonothe

tohoto oho 4 llow

obontos an

on wando foro

tom 1 oolone

$1 \mathrm{Wts} t$

who hs $\mathrm{m} \alpha \mathrm{d}$

mpon the poople

on owopololomo

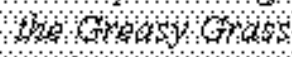

tuttle $\mathrm{b} \mathrm{g} / \mathrm{mon}$

0 motonsostt

nombered for

$1+k+16 m$

by fommo

opppspohdm

whowonof

sintons 2 w

menonals

and the rolold

$\mathrm{Akt} O W t \sigma$

monrent

denthos

the poople

hatato $\phi k t$

\section{Conclusions}

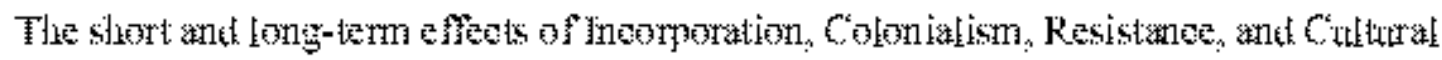

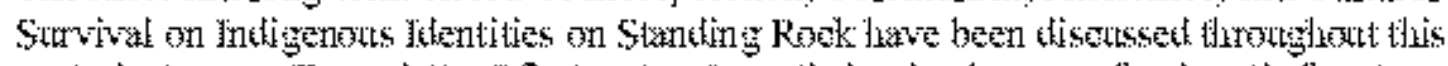

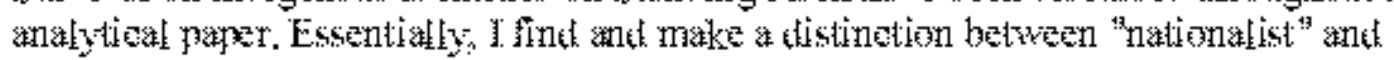

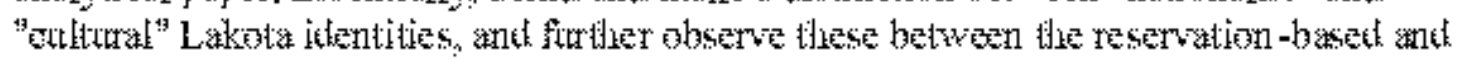

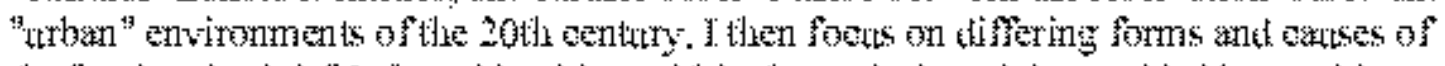

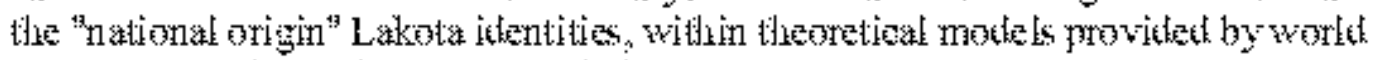
sytems analyis and intzrnal ooloniatism.

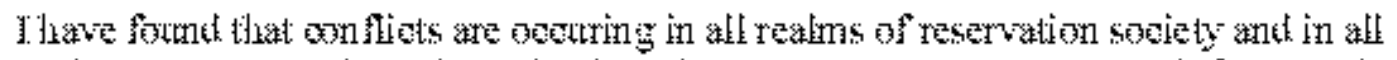

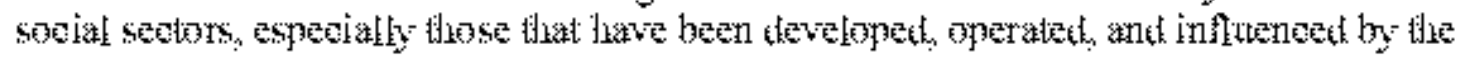

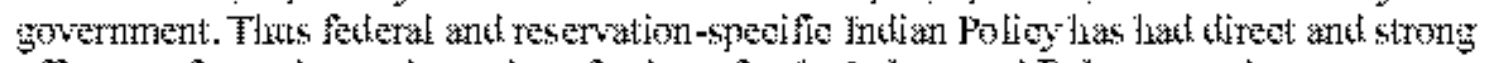

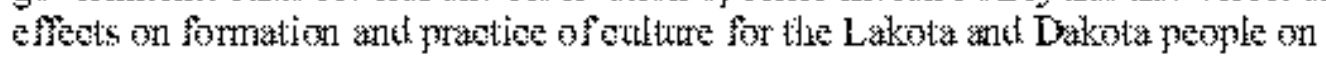

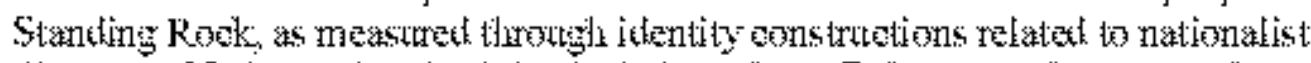

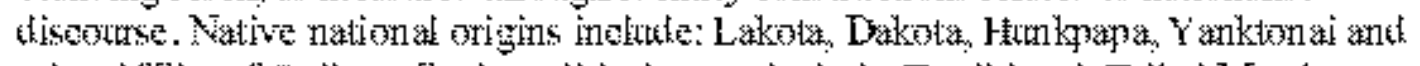

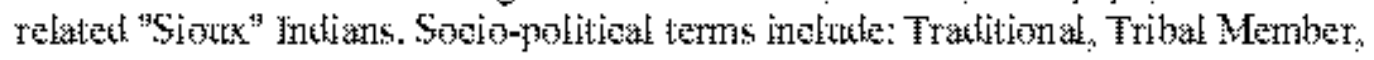


Assimilated, BIA Agents, and related functions of Tribal Councils. Contested cultural labels include: Native, Sioux, Indian, Tribe and most of the above. Political orientations include: American, Indigenous, Activist, Separatist, and sometimes blood quantum, such as "full-blood" or "mixed-blood."

These differences might be made complementary in a movement to redress the grievances of indigenous peoples, such as with the Lakota on Standing Rock, only when there is greater agreement as to the definition and meanings of these labels and identities. Additionally, collective actions with a focus on either Standing Rock reservation as likea-nation or tribe, or on a Lakota and Dakota Oyate approach, are the only likely avenues of political redress with positive results. Whether these are possible movement activities, mostly depends on how socio-political identities are worked out in the coming years. To that analysis we now turn.

[Page 301]

Journal of World-Systems Research

\section{Conclusions on Identity and Social Change}

Multiple types and sources of indigenous identity exist among the native American Indian people associated with Standing Rock reservation "nation". All of these are influenced by the historical relationships between the Lakota and the United States policies of cultural domination. Most indigenous identity forms are "constructed" from various socio-political sources, first intentionally by the U.S. Indian policy, and then through the resistance of the Lakota people.

In fact, Standing Rock as a "Sioux Indian Reservation" and more recently as a "Nation" are both direct evidence of these constructions of socio-political identity. Additionally, many "traditionals" and the recent AIM "activists" make cultural and political claims to "Lakota Oyate" from which they derive strength to resist ongoing socio-political and cultural domination. Thus, embattled identities actually perpetuate indigenous resistance to assimilation.

The four major temporal periods are related to current constructions of Lakota identities, in: "Oceti Sakowin" alliances of "traditional" resistance; "Sioux Nations" treaties leading to Progressives as "friendlies" resistance as "hostiles" as traditional Lakota culture is repressed; "Sioux Indian" reservations with assimilation policies "councils," while the traditionalists resist; and Lakota "Nation" or "Tribe" assimilated progressives work in modern institutions, while "Traditionals" live Lakota culture, with Activists and BiCultural modern Lakota.

I find four overlapping, external identities in existing typologies: "progressive" (friendly), "resistance" (resist change), "assimilated" (adapted) and "traditional" defined by responses to external forces of domination, incorporation, elimination and repression by U.S. expansion. 
Indigenous identities on Standing Rock have undergone enforced and responsive social change processes resulting in complex, interwoven forms of Indian identity. Differing levels of "assimilation" and "political participation" or conversely "traditional life" and "spirituality" only partially explain the long chain of conflicting claims, events, policies and resistance processes. Movement from being "Lakota" as membership in a "tiyospaye" and ultimately an "oyate" extending through the "Sioux Nation of Indians" and "tribal" membership as a "Sioux Indian" returning full circle to claims of "Lakota" and "Dakota" membership of "Standing Rock Nation" with the penultimate claims to being an "oyate" - all demonstrate these complex processes better, when combined with the effects of internal colonialism, cultural genocide, and the systemic repression of the 20 th century.

[Page 302]

Journal of World-Systems Research

Each of the four major politically influenced movements -- from Oyate in Oceti Sakowin; to Sioux Nation (Lakota); to separated Sioux Reservations (Standing Rock); to the autonomous Standing Rock as Nation; -- caused divisive and integrative changes in individual identity forms. Along with levels of assimilation, maintenance of traditional lifeways, and resistance spirituality, the cultural and socio-political identity of the Lakota on Standing Rock has become a fragmented, multi-dimensional mosaic that harkens to the past as much to the future.

Thus I can state, based on the above findings and observations, that identity constructions related to historical policies and conflicts, will not recede in importance. Instead, they will change reflexively depending on three major issues: contemporary U.S. political and economic treatment, collective interests and actions of the Native people on Standing Rock, and the broader American society's ideologies of Native Nations and American Indians. Each of these are identity issues -- political policies, collective action, dominantsubordinate relations -- that represent racial-ethnic, inequality, and social movement perspectives indicative of the growing diversity in the American society in which indigenous people must live and interact.

Traditional and modern Lakota and Dakota "Sioux Indians" from Standing Rock continue to use one phrase which represents this cultural mosaic, -- "o-Mitakuye Oyasin"-- which means "we are all related" -- demonstrating the respect for all of one's relations that make up identity.

\section{REFERENCES AND WORKS CITED}

AILTP, American Indian Lawyer Training Program. (Wilkinson, C.A.) 1988. Indian tribes as sovereign governments. Oakland, CA: American Indian Resources Institute, AIRI Press.

Axtell, James. 1985. The invasion within: the contest of cultures in colonial North America. New York: Oxford University Press. 
[Page 303]

Journal of World-Systems Research

Berkhofer, Robert F. 1978. The white man's Indian. Reprint, 1979. New York: Random House.

Big Horse, Renfrew (pseudonym). 1993. Interview given at the "Indigenous Voices and Genocide Meetings" in Chicago, 10/24/93

Biolsi, Thomas. 1992. Organizing the Lakota: the political economy of the New Deal on the Pine Ridge and Rosebud reservations. Tucson: University of Arizona Press.

Black Elk, Frank. 1983. "Observations on Marxism and Lakota tradition" Marxism and Native Americans. Ed: Ward Churchill. Boston, MA: South End Press.

Blauner, Robert. 1972. Racial oppression in America. New York: Harper and Row.

Blaut, J.M. 1989. "Colonialism and the rise of capitalism." Science and Society, v53, p260-96, Fall 1989. Discussion 54, Spring 1990; 55, Winter '91/'92.

Brown, Dee. 1970. Bury my heart at Wounded Knee: an Indian history of the American West. New York: Holt, Rhinehart, and Winston

Brown, Joseph Epes. 1953. The sacred pipe. Baltimore: Penguin Books, 1971.

Cadwalader, Sandra D. and Vine Deloria (Eds). 1984. The Aggressions of civilization: federal Indian policy since the 1880's. Philadelphia: Temple University Press.

[Page 304]

Journal of World-Systems Research

Castile, George P. 1992. "Indian sign: hegemony and symbolism in federal Indian policy" in State and reservation, new perspectives on federal Indian policy. Editors: George Castile and Robert Bee. Tucson: University of Arizona Press. 1992.

Champagne, Duane. 1992. "Organizational change and Conflict: a case study of the Bureau of Indian Affairs" in Native Americans and public policy. Editors: Lyden and Legters. University of Pittsburgh Press.

Chase-Dunn, Christopher. 1980. "The Development of Core Capitalism in the Antebellum United States: Tariff Politics and Class Struggle in an Upwardly Mobile Semiperiphery." Studies of the Modern World-System, ed.: Albert Bergesen. New York: Academic Press. 
Churchill, Ward. 1992. "Implications of treaty relationships between the United States and various American Indian Nations" in Native Americans and public policy. (Editors: Lyden, F, and Legters, L.). Pittsburgh: University of Pittsburgh Press. 1992.

Clifford, James. 1988. The Predicament of Culture. Cambridge: Harvard Univ.Press.

Cornell, Stephen. 1988a. "The transformations of tribe: organization and self-concept in Native Americans ethnicities." Ethnic and Racial Studies. v11, p27-47, January '88.

Cornell, Stephen. 1988b. The Return of the native: American Indian political resurgence. Oxford Univ. Press: New York.

Cornell, Stephen and Kalt, Joseph P. 1993. "Where does economic development really come from? Constitutional rule among the modern Sioux and Apache." Project on American Indian Economic Development. Cambridge: Malcolm Weiner Center, Harvard Univ.

Coulter, Robert and Tullberg, Steven. 1984. "Indian land rights" in The Aggressions of civilization, federal Indian policy since the 1880's edited by Sandra Cadwalader and Vine Deloria, Jr.. Philadelphia: Temple University Press.

Crawford, James. 1995. "Endangered Native American languages: what is to be done, and why?" in The Bilingual Research Journal, Winter 1995, Vol.19, No.1, pp. 17-38.

Defender, M.L.. Oral tradition "interviews" in 1994, 1992, 1991, 1989, and 1987. Also from "The Taken Land" and "North Dakota Centennial Logo" co-authored pamphlets.

Defender Wilson, Mary Louise. 1996. Lecture given at John Carroll University, April 15, 1996, entitled "Native American Spirituality and the Environment." (Oral tradition talk).

Deloria, Ella C. 1979 [1933]. Speaking of Indians. Vermillion, SD: Dakota Press.

Deloria, Ella Cara. 1990 [1948]. Waterlily. Lincoln: Univ. of Nebraska Press.

[Page 305]

Journal of World-Systems Research

Deloria, Philip J. 1993. "The Twentieth century and beyond." in The Native Americans, Editors: Thomas, D.H., Miller, J., White, R. Nabokov P. and Deloria, P. Atlanta: Turner Pub. Inc.

Deloria, Vine Jr. 1973. God is Red. New York: Dell Publishing.

Deloria, Vine, 1979. The metaphysics of modern existence. San Francisco: Harper \& Row. 
Deloria, Vine Jr. 1984. "'Congress in its wisdom": the course of Indian legislation" in The Aggressions of civilization, federal Indian Policy since the 1880's Eds: S.

Cadwalader \& V. Deloria, Jr. Philadelphia: Temple University Press.

Deloria, Vine (Editor). 1985. American Indian policy in the twentieth century. Norman: University of Oklahoma Press.

Deloria, Vine, Jr. 1987 [1981 in Daedelus]. "Identity and culture" in From different shores, perspectives on race and ethnicity in American (2nd ed.) Editor: Ronald Takaki. New York: Oxford University Press, 1994.

Deloria, Vine Jr. 1990. "Knowing and understanding" Vol. 5, No. 1. Winds of Change. Autumn, 1990. ....also see Deloria, Vine. 1991. Indian education in America. American Indian Science and Engineering Society. Boulder, Colorado: AISES.

Deloria, Jr. Vine, and Lytle, Clifford M. 1984. The Nations within, the past and future of American Indian sovereignty. New York: Pantheon Books.

DeMallie, Raymond, editor. 1984. The Sixth grandfather. Lincoln: University of Nebraska Press.

Drinnon, Richard. 1986. Keeper of concentration camps: Dillon S. Meyer and American racism. Berkeley: University of California Press.

Duchene, M. 1988 "GIANT LAW, GIANT EDUCATION and ANT: a story about racism and Native Americans" in Facing racism in education edited by Hidalgo, McDowell and Siddle. 1992. Cambridge, MA: Harvard Ed. Review.

Dunaway, Wilma A. 1996. The First American Frontier: Transition to Capitalism in Southern Appalachia, 1700-1860. Chapel Hill: University of North Carolina Press.

Eastman, Charles "Oyihesa". 1911. The soul of the Indian: an interpretation. Lincoln: University of Nebraska Press. 1980.

Erdoes, Richard. 1982. Native Americans, the Sioux. edited by Marvin Reiter. New York: Sterling Publishing Co.

Erikson, Erik H. 1963. Childhood and society. New York: Norton.

Fenelon, James. 1991. "Native Americans: From Christopher Columbus to Curriculum Integration" Chapter 10 in Multicultural Education : Strategies for Implementation in Colleges and Universities. Macomb: Western Illinois University Press.

[Page 306]

Joumal of World-Systems Research 
Fenelon, James. 1997. "Indian Gaming: Perspectives From Modern and Traditional Native Worlds" for the "Indian Gaming: Who Wins?" Conference, American Indian Studies Center and School of Law, UCLA, Los Angeles, CA.

Fenelon, James. (forthcoming) "Urban Indians: Discrimination and Social Change in Chicago."

Fishman, Joshua A. 1991. Reversing language shift: theoretical and empirical foundations of assistance to threatened languages. (Clevedon) Philadelphia: Multilingual Matters.

Fixico, Donald. 1986. Termination and relocation, federal Indian policy $1945-1960$. Albuquerque: University of New Mexico Press.

Fleras, Augie and Elliott, Jean L. 1992. The 'Nations within' aboriginal - state relations in Canada, the United States, and New Zealand. New York: Oxford University Press.

Fools Crow. 1979. Fools Crow. Recorded, edited by Thomas Mails, and Dallas Chief Eagle. Garden City, N.Y.: Doubleday.

Forbes, Jack D. 1991. "Envelopment, proletarianization and inferiorization: aspects of colonialism's impact upon Native Americans and other people of color in Eastern North America" Journal of Ethnic Studies, v18 p95-122, Winter 1991.

Fried, Morton H. 1975. The Notion of tribe, Menlo Park: Cummings Publishing.

Geertz, Clifford. 1973. The Interpretation of cultures. NY: Basic, Harper Collins.

Gill, Sam D. 1987. Mother Earth: Native Americans and the land. Univ.of Chicago Press.

Goodman, Ronald. 1992. Lakota star knowledge. Rosebud, SD: Sinte Gleska University.

Grass-man, (pseudonym) 1993. interview given at the "Indigenous Voices and Genocide Meetings" in Chicago, 10/24/93 .

Green, Michael K. 1995. "Cultural Identities: Challenges for the Twenty-First Century" in "Issues in Native American Cultural Identity" edited by Michael K. Green, New York: Peter Lang Publishing. 1995.

Greene, Jerome. 1994. Lakota and Cheyenne: Indian Views of the Great Sioux War, 1876-1877. Norman, OK: University of Oklahoma Press.

Grinde, Donald A. 1995. "Historical Narrative of Nationhood and the Semiotic Construction of Social Identity: A Native American Perspective." in "Issues in Native American Cultural Identity" edited by Michael K. Green, New York: Peter Lang Publishing. 1995. 
Hall, Thomas D. 1984. "Lessons of long-term social change for comparative and historical study of ethnicity." Current Perspectives in Social Theory, 5:121-144, '84.

[Page 307]

Journal of World-Systems Research

Hall, Thomas D. 1986. "Incorporation in the World-System: Toward A Critique." American Sociological Review 51 (June):390-402.

Hall, Thomas D. 1989. Social change in the Southwest, 1350-1880. Lawrence, KS: University of Kansas Press.

Hamley, Jeffrey. 1994. "Cultural genocide in the classroom: a history of the federal boarding school movement in American Indian education, 1875-1920". Doctoral dissertation, Harvard University.

Harff, Barbara. 1987. "Etiology of genocides" in Genocide and the modern age: Etiology and case studies of mass death. Editors: Isidor Wallimann and Michael Dobkowski. New York: Greenwood Press.

Harmon, Alexandra. 1990. "When Is an Indian not an Indian? the "Friends of the Indian" and the problems of Indian identity." Journal of Ethnic Studies. v18, p95-123, Summer 1990.

Hechter, Michael. 1975. Internal colonialism: the Celtic Fringe in British national development, 1536-1966. Berkeley: University of California Press.

Hopkins T.K. and I. Wallerstein (Eds.). 1980. Processes of the world-system. Beverly Hills: Sage.

Horowitz, Irving. 1982 [1976].Taking lives: genocide and state power. Transaction.

Hoxie, Fred. 1984. Final promise: the campaign to assimilate the Indians. Lincoln: University of Nebraska Press

Hurtado, Albert and Iverson, Peter. 1994. Major problems in American Indian history: documents and essays. Lexington, MA: D.C. Heath.

Jaimes, Annette M. 1988. "Federal Indian identification policy: a usurpation of indigenous sovereignty in North America."Policy Studies Journal, v16, p778-98, Sum 1988.

Jaimes, Annette. Ed. 1992. The State of Native America - genocide, colonization and resistance. Boston: South End Press.

Jarvenpa, Robert. 1985. "The Political economy and political ethnicity of American 
Indian adaptation and identities" Ethnic and Racial Studies, vol.8 (29-48)

Jennings, Francis. 1975. The Invasion of America - Indians, colonialism and the cant of conquest. New York: W.W. Norton \& Company.

Jensen R., Paul R., Carter J. 1991. Eyewitness at Wounded Knee. Lincoln: U. of Nebraska Press.

Johansen, Bruce E. 1982. Forgotten founders, how the Indian helped shape democracy. Boston: Harvard Common Press.

[Page 308]

Journal of World-Systems Research

Johnson, Troy, 1996. "The American Indian Occupation of Alcatraz Island, 1969 - 1971." http://ark.acs.csulb.edu/gc/libarts/am-indian/alcatraz/index.html

Josephy, Alvin M. 1992. America in 1492: the world of the Indian peoples before the arrival of Columbus. New York: Knopf (Random House)

Kalt, J. and Cornell, S. 1989. Pathways from poverty. The Harvard Project on American Indian Economic Development. Cambridge, MA: Harvard University.

Kardulias, P. Nick. 1990. "Fur Production as a Specialized Activity in a World System: Indians in the North American Fur Trade." American Indian Culture and Research Journal (UCLA) 14:1:25-60.

Lawson, Michael. 1982. Dammed Indians. Norman, OK: University of Oklahoma Press.

Lazarus, Edward. 1991. Black Hills, white justice. the Sioux Nation versus the United States, 1775 to the present. New York: Harper Collins.

Legters, Lyman H. 1992. "The American Genocide" in Native Americans and public policy. (Editors: Lyden, F, and Legters, L.). Pittsburgh: University of Pittsburgh Press.

Locust, Carol. 1988. "Wounding the spirit: discrimination ...." in Facing racism in education Ed.: Hidalgo, McDowell and Siddle. 1992. Cambridge, MA: Harvard Educational Review.

Mails, Thomas E. 1972. The mystic warriors of the plains. Garden city, N.Y.: Doubleday. Matthiessen, Peter. 1991 (1983). In the spirit of Crazy Horse. New York: Viking Penguin.

McGaa, Ed "Eagleman". 1994. Personal conversations, based on his work Mother Earth spirituality, San Francisco: Harper-Collins. 1990. 
McLaughlin, James. 1910. My Friend the Indian New York: Houghton Mifflin.

Means, Russell. 1983. "The Same Old Song" in Marxism and Native Americans. Ed: Ward Churchill. Boston, MA: South End Press.

Meyer, Melissa L. 1994. The White Earth Tragedy: Ethnicity and Dispossession at a Minnesota Anishinaabe Reservation, 1889- 1920. Lincoln: University of Nebraska.

Meyers, Roy W. 1980. History of the Santee Sioux, United States Indian policy on trial. Lincoln: University of Nebraska Press (Bison). First printing, 1967.

Mooney, James. 1896. The Ghost Dance religion and Wounded Knee. New York: Dover. 1973.

Nagel, Joane. 1984. "The Ethnic revolution: the emergence of ethnic nationalism in modern states" Sociology and Social Research, v68, p417-34, July 1984.

O'Brien, Sharon. 1989. American Indian tribal governments. Norman: University of Oklahoma.

Olson, James C. 1965. Red Cloud and the Sioux problem. Lincoln: University of Nebraska.

[Page 309]

Journal of World-Systems Research

O'Nell, Theresa Deleane. 1996. Disciplined Hearts: History, Identity, and Depression in an American Indian Community. Berkeley, CA: University of California Press.

Ortiz, Roxanne D. 1977. The Great Sioux Nation, sitting in judgement on America.Moon Books.

Ortiz, Roxanne Dunbar. 1984. Indians of the Americas, human rights and selfdetermination New York: Praeger.

Parman, Donald Lee. 1994. Indians and the American West in the twentieth century.

Peterson, Patricia M. 1991. Appendix B - "Cultural perspectives" in Cante ohitika Win (Brave-hearted women) by Carolyn Reyer. Vermillion, SD: University of South Dakota Press.

Pommersheim, Frank. 1977. Broken ground and flowing waters. Aberdeen: North Plains Press.

Powers, William K. 1986. Sacred language - the nature of supernatural discourse in Lakota. Norman: University of Oklahoma Press. 
Powers, William K. 1987. Beyond the vision: essays on American Indian culture.

Norman: University of Oklahoma Press.

Prucha, Francis (ed). 1978. Americanizing the American Indians. Lincoln: U. of

Nebraska Press.

Prucha, Francis. 1984. The Great Father, the United States government and the American Indians. Lincoln: Univ. of Nebraska Press.

Red Horse, John G. et al. 1978. "Family behavior of urban American Indians." Social Casework, 59: 69-72, 1978.

Reyer, Carolyn. 1991. Cante Ohitika Win (Brave-hearted Women). Vermillion, SD:

University of South Dakota Press.

Riggs, Stephen Return. 1869. Tah-koo wah-kan; or, The gospel among the Dakotas.

Boston: Congregational Sabbath School and Publishing Society.

Ronda, James P. 1984. Lewis and Clark among the Indians. Lincoln: University of Nebraska.

Russell, James W. 1994. After the Fifth Sun, class and race in North America.

Englewood Cliffs, NJ: Prentice Hall.

Scott, James. 1990. "Voice under domination: the arts of political disguise" in Domination and the arts of resistance. Yale University Press.

Skocpol, Theda. 1984. "Introduction" to Vision and method in historical Sociology.

Editor T. Skocpol. New York: Cambridge University Press.

Smelser, Neil. 1992. "Introduction" in Theory of culture, Editors: Munch, Richard and Smelser, Neil J. Berkeley: University of California Press.

[Page 310]

Journal of World-Systems Research

Snipp, Matthew. 1986. "The Changing political and economic status of American Indians: from captive Nations to internal colonies." American Journal of Economics and Sociology, 45:2 (April), 145 57, 1986.

Snipp, Matthew C. 1989. American Indians: the first of this land. New York: Russell Sage Foun.

Snipp, Matthew and Joan Nagel. 1992. The Reorganization of American Indian ethnicity. Unpublished manuscript, presented at Wisconsin's Race and Ethnicity Colloquium, $11 / 30 / 92$. 
Spicer, Edward H. (Ed.) 1961. Perspectives in American Indian cultural change. Chicago: University of Chicago Press.

Spindler, George and Louise, with H. Trueba and M.D. Williams. 1990. The American cultural dialogue and its transmission. New York: Falmer Press.

Standing Bear, Luther. 1933. Land of the Spotted Eagle, by Chief Standing Bear. Boston: Houghton Mifflin Company.

Stannard, David E. 1992. American holocaust, Columbus and the conquest of the New World. New York: Oxford University Press.

Stiffarm, Lenore A. with Lane, Phil. 1992. "The Demography of Native North America: a question of American Indian survival" in The State of Native America. (Ed.) M. Annette Jaimes. Boston, MA: South End Press.

Strickland, Rennard. 1992. "Native Americans" (pgs. 577-581) in The Oxford Companion to the Supreme Court of the United States. Editor: Kermit Hall; w/ Ely, J., Grossman, J., Wiecek, W. New York: Oxford University Press.

Sundance, Robert, with Gaede, Marc. 1994. Sundance : the Robert Sundance story. La Canada, CA : Chaco Press.

Thompson, John B. 1990. Ideology and modern culture. Stanford: Stanford Univ. Press.

Thornton, Russell. 1987. American Indian holocaust and survival. Norman: University of Oklahoma Press.

Tilly, Charles. 1978. From mobilization to revolution. Reading: Addison Wesley.

Tilly, Charles. 1984 As Sociology meets history. New York: Academic Press.

Trigger, Bruce. 1986. "Ethnohistory: the Unfinished Edifice." Ethnohistory, 33:3 (Summer) pp.253-67.

U.N. Commission on Human Rights, Economic and Social Council. 1992.

"Discrimination Against Indigenous Peoples".

[Page 311]

Journal of World-Systems Research

Utley, Robert M. 1984. The Indian frontier of the American West 1846 - 1890.

Albuquerque: University of New Mexico Press.

Utley, Robert. 1993. The Lance and the shield, the life and times of Sitting Bull. New

York: Henry Hold and Company. 
Vestal, Stanley. 1932. Sitting Bull: champion of the Sioux NY: Houghton Mifflin.

Walker, James R. 1980. (DeMallie and Jahner, Ed.s) Lakota belief and ritual. Lincoln: University of Nebraska Press. (Reprint in 1991)

Walker, James R. 1982. (R. DeMallie, Ed.) Lakota society Lincoln: Univ. of Nebraska Press.

Walker, James R. 1983. (E. Jahner, Ed.) Lakota myth. Lincoln: University of Nebraska Press.

Wallerstein, Immanuel. 1991. Geopolitics and geoculture. New York: Cambridge Univ. Press.

Walking, John (pseudonym). 1993. Interview given at the "Indigenous Voices and Genocide Meetings" in Chicago, October, 1993.

Weatherford, Jack. 1988. Indian givers, how the Indians of the Americas transformed the world. New York: Fawcett Columbine.

Weatherford, Jack. 1991. Native roots: how the Indians enriched America. New York: Ballantine Books.

White, Richard. 1978. "Winning of the West: the Expansion of the Western Sioux in the Eighteenth and Nineteenth Centuries." in Major problems in American Indian history

Eds.: Hurtado A. and Iverson P. Lexington, MA: D.C. Heath and Company. 1994.

White Hat, Albert and Arounds Him, John. 1990. Lakota ceremonial songs, Mission, SD: Sinte Gleska University.

Wilkinson, Charles F. 1987. American Indians, time and the law: Native societies in a modern constitutional democracy. New Haven: Yale University Press.

Wolf, Eric R. 1982. Europe and the people without history. Berkeley: University of California Press.

Wooster, Robert. 1988. The Military and the United States Indian policy, $1865-1903$. New Haven: Yale University Press.

Wunder, John R. 1994. "Retained by the people": a history of American Indians and the Bill of Rights. New York: Oxford University Press.

Yellow, Frances. 1994. Oral tradition interviews. $(1993,1992)$

[Page 312]

Journal of World-Systems Research 
Young Bear, Severt and Theisz, R.D. 1994. Standing in the light, a Lakota way of seeing. Lincoln: University of Nebraska Press.

1. I am particularly sensitive to this having just returned from presenting " The Cultural Domination of the Lakota Oyate" at the National Indian Education Association in Rapid City to a largely Lakota/Dakota audience (October, 1996).

2. The accounts are too numerous. One standard historical story: Anderson, Gary Clayton, "Early Dakota Migration and Intertribal War: A Revision,"Western Historical Quarterly, 11 (1980) 17-36.

3. This discussion is incredibly complex and methodologically controversial in anthropology, versus an oral tradition perspective. Lakota traditions have an "origin place" in the Black Hills, suggesting ancient knowledge if not direct experience in western South Dakota (Goodman, 1992). Moreover, the buffalo play a heavy part in all Lakota culture, with "Pte Oyate" as a central thematic creation story (Defender, 1989). Cultural evidence suggests familiarity with western Dakotas.

4. I can place some Lakota groups in the western Dakotas, including the Black Hills, in the sixteenth century, and earlier. As noted, "documented" histories can be shown to be false, including Utley's supposition that the "Lakota culture was hardly a generation old at the time of Sitting Bull's birth" (1993:4), attributed to western migration and development of the horse. Another note are the early explorers such as Verendrye (Thornton, 1986) and trader-"explorers", maintaining economic relations and fur trade long before hypothesized dates of academia. Lewis and Clark are given explicit instructions as to the "immense power" of the Lakota Sioux along the Missouri by no less than the President of the United States. Finally, while northern Dakota were pushed from the north by the Chippewa (Ojibwa) and Cree, there does not have to be a causative migration by the Lakota.

5. In fact, the most informed traditional elders hold that Lakota and Dakota refer to people groups, and thus are Oyate, while the dialects are Santee Dakota I-Santee, Yankton(ai) Dakota Wicheyena, and the Lakota Titonwan. While these may roughly conform to the $\mathrm{L}$ and $\mathrm{D}$ dialects, distinctions between the cultural relationships as "people groups" are very important.

6. Theory applied frames: cultural domination (Smelser, 1992), institutional legitimation (Weber, 1956), cultural hegemony (Gramsci, 1929), and historical (Toynbee, 1953). Lakota identity was further influenced in resistance (Scott, 1990) and Clifford (1988), within political structures (Deloria, 1983) (Cornell, 1988). Analysis by (Hall, 1984), Thornton (1987), Wolf (1982) show adapted resistance and survival (Snipp, 1989). 
7."...natives were to understand that they possessed a choice of peace or war as a result of the history of God's creation of the world and patronage of the Catholic Church."

(Berkhofer, 1979:123)

8. (Luther Standing Bear, Lakota-Sioux) The quote is taken from Standing Bear (1933), Land of the Spotted Eagle, as reported by Bruce Johansen (1982:xi) in Founding Fathers

9. Historical (Robinson, 1904) and anthropological (DeMallie, 1971) sources.

10. There is extensive literature on social organization of the Dakota, often called the Santee Sioux, and the Lakota, known as the Teton Sioux (Walker, 1982, 1983, 1985 [1914]) (Wissler, 1917) (Deloria, 1933). DeMallie (1987; 1984) makes a Lakota description on Walker's work (1982).

[Page 313]

Journal of World-Systems Research

11. The Oceti Sakowin constituted the Lakota Oyate as one of seven greater council fires, shared with the Wo-Dakota Oyate, and the Nakota. United States economic and political interests caused some differential treatment by 1804 .

12. Two separate nations existed for the U.S. government negotiators by 1851 , ironically both the Dakota and Lakota treaties were signed with the "Sioux Nation of Indians". After the destruction and diaspora of the Dakota from the 1862 conflicts in Minnesota, the U.S. Fort Laramie Treaty of 1868 with the "Sioux Nation of Indians" meant only the Lakota.

13. Dakota before, constituted geo-political.... Lakota as forested fringe, before horse 1804 "SIOUX" - (Lakota / Dakota Alliances) 1851 "SIOUX NATION OF INDIANS" 1868 "SIOUX NATION OF INDIANS" - Fort Laramie Treaty 1890 SIOUX AGENCIES - (reservations) 1934 "STANDING ROCK SIOUX TRIBE" - (reservations as tribes) 1990 STANDING ROCK "NATION" - (Standing Rock Sioux Reservation)

14. By 1889 , with U.S. instigated conflicts in 1876 and land-takings throughout the 1880 's, the Indian agencies became separate reservations, replacing the Great Sioux Reservation. These were treated politically separate in the 1934 IRA re-organization that denoted each reservation as a tribe (Standing Rock Sioux had Sihasapa and Hunkpapa Lakota, and Yanktonai Dakota).

15. Tilly (1975) discusses these machinations of war in Western society in terms that transfer exceptionally well for explaining the conquest of the North American continent.

16. "The Indian civilizations crumbled in the face of the Old World not because of any intellectual or cultural inferiority. They simply succumbed (to) face brute strength. (Weatherford, 1991:252) 
17. The rights of Native Americans as well as their land and resources continue to be eroded. If scholars are to be of service in this area of research, they urgently need to confront the realities of more recent Indian affairs and to place these important events in historical perspective. (Lawson, 1982:199).

18. "Sioux" is complex with ethnic and temporal-spatial variations. (Powers, 1975:3-10).

19. Most scholars agree, as do most Lakota researchers, that the term originates from a French-Cree mangling of the word "Nadewasue" which apparently was used by the Ojibwa-Chippewa, traditional enemies of the Dakota, and meant "snake-like" or cutthroat "enemies".

20. Powers (1975) effectively groups the three categories as: Political, Dialectical, Geographic

21. "The history of the Santee Sioux is the history of the American Indian. mutually profitable early contacts with Europeans were followed by a massive onslaught on the native culture... Then came forced land cessions, removal to a reservation, smoldering resentment that erupted in a bloody but abortive protest, vindictive punishment, and a long, dismal period of attempted acculturation, ending in poverty and demoralization." (Roy W. Meyers, 1980:371 (1967), The Santee Sioux, United States Indian Policy on Trial.)

22. These are contested both as socio-cultural and or political groupings, with some researchers and ethnohistorians stating that the construction is from the various Sioux peoples themselves, and without proof must remain myth, although they do say that since the Sioux do not differentiate across time, it doesn't matter anyway. Besides an obvious problem that calling it "myth" simply because they cannot document it, I say it doesn't matter.

[Page 314]

Joumal of World-Systems Research

23. (16 Stat. 566, 25 U.S.C. $\$ 71$ (1976) No Indian nation or tribe within the territory of the United States shall be acknowledged or recognized as an independent nation, tribe or power with whom the United States may contract by treaty; but no obligation of any treaty lawfully made and ratified with any such Indian nation or tribe prior to March third, shall be hereby invalidated or impaired.

24. Temporal and spatial contexts varying in any analysis, especially those involving incoming societies (Wolf, 1982) with implications of "World Systems" domination (Hopkins \& Wallerstein, 1980) call for clear delineation of analytical frames, in this case study extending from Oceti Sakowin to Lakota Oyate to the six Sioux Reservations.

25. The man who sat on the ground in his tipi meditating on life and its meaning, accepting the kinship of all creatures and acknowledging unity with the universe of things 
was infusing into his being the true essence of civilization... In the Indian the spirit of the land is still vested, it will be until other men are able to divine and meet its rhythm. (Luther Standing Bear, Lakota)

26. "Thus the Indian is reconstructed, as the natural rocks are ground to powder and made into artificial blocks which may be built into the walls of modern society." (Ohiyesa, Charles Eastman, Dakota)

27.In developing a meaningful discussion of the conquering American social systems and the dominated Lakota-Sioux society over time and space, we have to engage the mythical and real dimensions of something referred to as the "frontier" of American development, inevitably that of Euro-Americans in a large state structure building an empire over smaller Indian nations.

28. The "myth" of the Frontier, built on the above set of conquests, was as much one made of these ideological confrontations as any cross-culturally conceived conflicts, sustained by developing fear and hatred among the soon -to-be dominant group of AngloAmerican "colonists" in New England, and similarly in the dominant Euro-American "pioneers" in developing the western portions of North America.

29. The language employed by the Puritan pilgrims in this domination over Native Nations, is perfectly synonymous with its natural corollary and ideological outgrowth local militia driven by singular interpretations of Manifest Destiny ideologies that prey upon, pray to and thank God for their actions as pre-ordained, including the killing and destruction of Native peoples en masse (Puritan language see Jennings, 1975; Olson and Wilson, 1984; and Takaki, 1994).

30. Culturicide requires elaborate ideologies that not only place one cultural or social group in a superordinate position and other(s) (mostly "racial" minorities) in various subordinated positions, but that also drive the continuing creation of cults, para-military groups, and similar over-intensified aberrations that view any other set of ideologies, even those originally creating their own, as suspect and potentially a threat.

31. Hidatsa-Mandan-Arikara leaders have told me about an armed standoff where two of these para-military hate groups (Aryan Nation and Posse Comitatus) had threatened an Indian boy and then come into the face-off with Indian men in the northeast sector of the Three Affiliated Tribes Fort Berthold Reservation in North Dakota. When the state police and federal marshals arrived, they did not know which group to square off with, and for once were caught in the middle.

32. In reviewing Lakota sociopolitical organization from the nineteenth century, Biolsi (1992:35) finds it "is best seen as seasonally and opportunistically variable along a continuum running from small units with little formal political structure to large units with more formal organization. Neither corporate groups nor fixed boundaries were characteristic of Lakota political organization, and units of all sizes were fluid." 
[Page 315]

Joumal of World-Systems Research

33. Perhaps the only Indian policy goal that Pick-Sloan helped advance was that of acculturation. For over a century the federal government has implemented policies designed to integrate Indians into the mainstream of Anglo-American culture. (Lawson, 1982:198).

34. The simple truth is that no matter what form a federal public works project takes, the odds are heavily stacked against Indians from the beginning. (Lawson, 1982:199).

35. Without addressing the history marked indelibly in the land, a history neither to be refuted nor "interpreted" thru ideological sophistry, no theory can be anchored. Since an unanchored theory must inevitably result in misunderstanding, it is the history of the land... (Laduke, Winona. 1983.)

36. ...'m more concerned with American Indian people, students and others, who've begun to be absorbed into the white world through universities and other institutions. ...It's very possible to grow into a red face with a white mind... This is part of the process of cultural genocide being waged by Europeans against American Indian peoples today. My concern is with those American Indians who choose to resist this genocide, but who may be confused as to how to proceed. (pg.1) Means, Russell. 1983.

37. Oahe Dam and related land-takings and so on...(1960's) Dammed Indians, Lawson 1982 .

38.1972 Indian Education Act (Title IV of the Education Amendments of 1972, PL 92 318)

39. United States v. Consolidated Wounded Knee Cases. 389 F. Supp. 235 (D. Neb. W.D.S.D., 1975): affd in major part, 8th Circuit Court of Appeals, July 15, 1976.

40. 1975 Indian Self-Determination and Educational Assistance Act (PL 93-638)

41. 1978 Indian Child Welfare Act (PL 95-608)

42. In United States v. Sioux Nation of Indians, 448 U.S. 371 (1980).

43. 1978 American Indian Religious Freedom Act (PL 95-195)

44. Repatriation Struggles were initiated in tandem with other related issues for Native Nations, just as Traditional societies were being revitalized in many Sioux- Lakota communities. At about the same time, the Oahe takings claim was revisited by Standing Rock Sioux. In 1987 the Black Hills claim was debated on the Sioux reservations, with many sides including the councils backing the Bradley bill, and others including some 
elder traditionals (the Grey Eagles) supporting the newly rediscovered part-Indian capitalist Stevens initiative.

45. 1988-1992 Indigenous Sovereignty Movements (i.e. Country of Lakota, U.N., others...), includes in this analysis, applying to the United Nations, and South Dakota Reconciliation.

46. This testimony, taken from Henry Swift Horse at his home outside Cannonball on the North Dakota side of the Standing Rock Sioux Indian reservation in November, 1987, along with the testimony from Reginald Bird Horse and Vernon Iron Cloud, both from the Grand River area, South Dakota side of the Standing Rock reservation, was reported in a short booklet "The Taken Land" submitted to the Senate Select committee on Indian Affairs (1987).

47. The particular photographs I am referring to were taken on Standing Rock by D.F. Barry and another set by Frank Fiske in the first two decades of the 20th century. Another pictures are less incontrovertible, such as one marked "Taking wagons to the SunDance outside of Cannonball".

[Page 316]

Journal of World-Systems Research

48. Understanding the nature of the cultural repression, domination and Culturicidal elimination against Lakota traditionals by the 20 th century U.S. policies and practices, informs the struggle for resistance to these pressures, and understanding of freedom and "cultural rights" in a world of highly codified "civil rights" that had banned religious and socio-cultural "rights" guaranteed in the constitution of the dominant society.

49. In many ways, this kind of ideological warfare being conducted by the FBI as policy, for instance in arresting Severt Young Bear for traditional drum singing, what the government considered "aiding and abetting" the resistance by AIM and Indian Nations activists, makes better evidence and even proof of system-wide conspiratorial repression of Lakota traditionals, than the ably and well-documented socio-political war conducted by the "agents of repression" as described by Churchill and Vander Wall (1990).

50. Severt Young Bear remembers: "...one day I went to Calico again. They were getting after everybody. It was mostly women and they were really mad. They told all the elderly men, medicine men, chiefs, and treaty people, "If you're not men enough to change things, take those pants off; we'll wear them if you can't stand up for us." (1994:149)

51. Severt Young Bear describes the conditions and predictions from that meeting and reality: "I was the youngest to be a spokesman or negotiator. There were six elderly men, three of them medicine men and three chiefs, who were appointed, all of them treaty people. I was the seventh... It was the first time in U.S. history, I believe, that the 82 nd Airborne was assigned somewhere in civilian clothes. They must be part of the Seventh 
Cavalry... The people who believed in treaties or lived the traditional way of life supported Wounded Knee II..."

52. Without historic analysis of Culturicide in policy and practice, analysts have a difficult if not impossible time in explaining the internecine violence which the United States used as its primary excuse to respond in military force to the "occupation" (or "siege") of Wounded Knee in 1973.

53. The federal marshals, unmarked military personnel in uniform, South Dakota militia, Pine Ridge GOON squads, the FBI, and a host of other state, federal, and governmental para-military forces besieged the Lakota/AIM occupants of the hamlet of Wounded Knee, for nearly three months, including air cover fire and mechanized heavy guns, amazingly leading to only one death. Not only is this position in clear alignment with its previous one hundred years of policy since the 1868 treaty, but the earlier division into separate agencies and sole recognition of individual councils, rather than the "Sioux Nation" or the "Lakota Oyate" as a collective group, is demonstrated in the conflict and its resolution.

54. Although the condemnation of the United States fits well into existing paradigms of military conquest and early genocidal policies, some of the language stresses credulity in assuming an undocumented (even by oral tradition) "Independent Oglala Nation"; and similarly identifies "genocidal practices against the sovereign Native Nations" as recently including the illustration of "Wounded Knee 1973" without either policy or practice targeting and resulting in multiple or mass death. A better typification would be to identify the policy in the U.S. "refusal to sign the United Nations 1948 Treaty on Genocide".

55. United States v. Consolidated Wounded Knee Cases. 389 F. Supp. 235 (D. Neb. W.D.S.D., 1975): affd in major part, 8th Circuit Court of Appeals, July 15, 1976.

56. Alex Chasing Hawk (Ortiz, 1977:134) states that: "I understand that during and after the signing of the 1868 Treaty the Sioux people have honored their promises that were made in the Treaty but that the United States government many times violated their own promises and have even made war against the Sioux Nation."

[Page 317]

Journal of World-Systems Research

57. "pipe-carrier" refers to having the responsibilities, and the rights, to perform the sacred pipe ceremony and to live one's life for "the people" in an honorable and truthful way. These responses are indicative of why group membership is helpful to the individual, and necessary for analysis.

58. "Full-blood" refers to a complicated and legally important ethnic differentiation for American Indians - blood quantum, tribal (BIA) enrollment, and cultural identification. "Activism" is further reference to socio-political struggle that supporting American Indian issues entails. 
59. This represents the typical ambiguity for "home-grown" urban Indians - as "panIndianism". For some urban Indians the connection to an originating home community is tenuous or non-existent, strengthening self-identification to the urban Indian ethnicity (Baldwin, 1992).

60. We can observe in these initial cross-section responses the tensions of identifying with a home mono-cultural community (reservation, Indian nation, etc.), and experiencing daily identification as an "Indian" in general among other "Indians" in an urban setting.

61. In United States v. Sioux Nation of Indians, 448 U.S. 371 (1980), the United States Supreme Court found the mammoth land-takings of the 1877 legislation, including the Black Hills, to be unconstitutional and therefore vacated under the Fifth Amendment.

62. Frank Fools Crow and Matthew Kills Enemy, of the Lakota Treaty Council, provided this testimony to the House Interior Subcommittee on Indian Affairs, September 10, 1976, as reported in (Fools Crow and Kills Enemy) O'Brien, 1989.

63. (The program they set up at the state hospital in Jamestown, made): "Qualifications for "Healers": ...like a profession, a Healer has to know a vocabulary (they qualify in four areas).

64. This testimony was collected and translated from the Lakota present by Severt Young Bear as reported, edited and written by: Ortiz, Roxanne Dunbar. 1977. The Great Sioux Nation, Sitting in Judgement on America. Moon Books, at Bookcrafters in Michigan. (pgs.183-184)

65. (...paraphrased into English to communicate the essence, not the exact words, of an eloquent speech given by this elder spiritual leader on his way to Washington D.C...)

66. Given to the Dakota and Lakota people assembled after the Wi-Wan-yang Wacipi ceremonies conducted for the second year, reinstituted for the M'deWakantowan Santee Sioux (Dakota) now residing on the Prairie Island Sioux reservation in Minnesota, in late June of 1994, partly in recognition of the 1993 SunDance held after one-hundred fifty years of repression.

[Page 318]

Journal of World-Systems Research

67. Mitakuyepi, My name is (Lakota traditional), my father's and my mother's people were (local tiyospaye), My grandfathers were and always have been of the M'niconjou people, of Lakota speakers and the seven council fires of the "oceti sakowin" including my good relatives here, the M'dw wakantowan Dakota people. ...We Lakota, and our relatives here the Dakota, originated from sacred places on earth, according to our sacred traditional knowledge. The Pte Oyate, we as the buffalo people, came out from the earth near the place where the holy winds blow out, very close to the Paha Sapa, the Black 
Hills, always known to us as the sacred "He Sapa". We know these things as the Wasicu know their origin place, and so it is. ....Another sacred place has been given to us to administer, the place now called Pipestone. Many hundreds of years before this time, the White Buffalo Calf Woman came to us and instructed the people, the oyate, on the sacredness of the pipe, and its importance in walking the good path in life. That is why we have gathered here today. ...My elder grandfathers, and their grandfathe rs before them, have listened and watched over our lifetimes, and told our observations to select young people, the future Lakota historians. We know these things, and have in this way seen them with our own eyes. I witnessed the coming of the wasicu unto our great plains, and how they killed the great numbers of buffalo, the birds with wings and the other fourleggeds. I witnessed their negotiations, and their leaders, each telling us he alone spoke for their people. ...My own grandfathers' relatives told us how the wasicu government hung your Dakota warriors nearby at Mankato, and sent our Dakota relatives, your people, into exile. I watched as their generals put pen to paper on the Fort Laramie Treaty of 1868 , surrendering their attack on the Black Hills or any of our lands west of the Missouri, and promising us peace, until their generals came, and my grandfathers wiped them out when they attacked us at the Greasy Grass, and again and again over that long winter. ...I am witness to how they have broken that treaty, and their words over the sacred pipe, for the years that followed, until they brought armies back to our lands and killed our visionary spiritual leader, Sitting Bull. I witnessed soldiers hunting down our people, and marching them to the Wounded Knee creek, where they killed us, revenge for having defended our people. I felt the pain of the people not having our SunDances, having ceremony in secret, and keeping the sacred tradition of the pipe alive.

Mitakuyepi, tonight we prepare to go to Washington, to President of the United States. We present a sacred pipe and ask him to think about these things, and do justice for our people, and return the sacred Black Hills to the Lakota, who will care for them and respect them as we have been taught to care for life on this earth....Mitakuye Oyasin.

68. "The Lakota Sovereignty Organizing Committee held meetings at Bear Butte on July 14,1991 , at which was present approximately 200 plus respected elders, women, children, spiritual leaders, keeper of the pipe, (and on...)..." resulting in declaration of: LAKOTA - a Sovereign Nation re-established at Bear Butte in July of 1991. THE COUNTRY OF LAKOTA AND A NATIONAL GOVERNMENT...

[Page 319]

Journal of World-Systems Research

69. Four interviewees responded in terms of urban Indian populations : PD -"...urban Indians looking for something... because they are different than the traditionals... FY "Grass roots organizing, people who have returned, have taken a spiritual path. JB "Groups are living in deep denial here by not looking at their own issues..." YM -"(But) Indian people resist change, and taking a risk...Tribal affiliations, even weak...affect leadership. 
70. Mythos of American development covered up the Aztecan, (Russell, 1994), Incan and Mayan (Wright, 1992) civilizations, and the unifying nations of the Iroquois (Snow, 1995), much less the looser confederacies of the Sioux. Theories of social hierarchy and evolution, building on earlier continental conquest justification, described Native cultural systems as if stratified on the levels of European civilization. Smelser examines social theorists with three framework examples,: Freud (1953) with "totemic systems and symbols in primitive religions" as dread of incest; Durkheim (1951) with "symbolic reflections on the social structures of the primitive societies", and Malinowski (1971) as "collective myths of social significance...(to) codify cultural beliefs and social behavior." Smelser (1992:19). We find that assumptions about social organization and control in societies, develops and drives theoretical observations and language about domination processes.

[Page 320]

Journal of World-Systems Research 